Publication citation: Merrony, C., Buckland, P., Dungworth, D., \& Parker Pearson, M. (2017). A prehistoric rock shelter burial site and enclosure at Scabba Wood, Sprotbrough, South Yorkshire. Yorkshire Archaeological Journal, 89(1), 23-60.

DOI: 10.1080/00844276.2017.1333339

\title{
A Prehistoric Rock Shelter Burial Site and Enclosure at Scabba Wood, Sprotbrough, South Yorkshire
}

\section{Colin Merrony, Paul Buckland, David Dungworth and Mike Parker Pearson*}

CONTACT: Colin Merrony, c.merrony@ sheffield.ac.uk

*With contributions by: Ben Chan, Andrew Chamberlain, Pat Collins, Chris Cumberpatch and Pia Nystrom.

\begin{abstract}
In 1992 two Middle Neolithic adult skeletons were excavated by South Yorkshire Archaeological Services from beneath a rock overhang at Scabba Wood (SE527019), near Sprotbrough, within one of the valleys north of the Don Gorge. In 1994, the Yorkshire Archaeological Society's Doncaster branch carried out a geophysical survey of a rectangular enclosure (SE530019), previously recognised by air photography, north-east of the wood, and in 1996 they began the excavation of a stone-walled, sub-rectangular enclosure within the wood, $150 \mathrm{~m}$ south of the rock overhang (SE530107). In 1997 and 1998 they were joined by a team from Sheffield University that also continued investigations at the stone-walled enclosure and along the rock overhang. Finds indicate occupation from the Late Iron and Roman period and Neolithic and Early Bronze Age use of the rock overhang for the disposal of the dead.
\end{abstract}

KEYWORDS Neolithic; Burials; Rock shelter; Iron Age; Roman; settlement 


\section{Location}

The dipslope of the Lower Magnesian Limestone forms a gentle east-sloping plateau falling from a maximum height of $100 \mathrm{~m}$ OD north of High Melton to approximately $25 \mathrm{~m}$ OD at Cusworth, where the outcrop is accentuated by the Don Fault downthrowing to the south-east. The River Don flows through the limestone in a narrow gorge which was probably cut subglacially ( $c f$ Gaunt 1994). Scabba Wood is located north of this, $3 \mathrm{~km}$ to the east of Doncaster at SE 530019 near the village of Sprotbrough, South Yorkshire (Figure 1). The archaeological sites are preserved in 8 ha of woodland formerly part of the Copley family's Sprotbrough Hall estate. The enclosure and rock overhang lie on the edge of a fault scarp at about $58 \mathrm{~m}$ OD, overlooking a narrow valley leading down into the Don Gorge at Sprotbrough Boat. In a cleared landscape the enclosure would have had extensive views in most directions, especially to the south-east where the ground falls away steeply into the valley.

\section{The area around the rock overhang and enclosure}

The limestone plateau overlooking the north bank of the Don between Cadeby in the west and Sprotbrough to the north-east is rich in Neolithic and later remains (Sainty 2007). Three long barrows are known to have existed in the immediate area, at SE501022 (Barnburgh; S. Yorks SMR 1864), SE500037 (Hangman Stone Hill, High Melton; S. Yorks SMR 1901), and adjacent to Hangman Stone (S. Yorks SMR 1212) (Magilton 1977: 10, 51). A fourth long barrow, King Hengist Rein (SE 526021), lay on the level ground $140 \mathrm{~m}$ north of Scabba Wood (Figure 2). Finds of Mesolithic, Neolithic and Early Bronze Age flintwork are wide- spread along the edge of the Magnesian Limestone plateau and either side of the Don valley (Magilton 1977; Sainty 2007; Pearce, unpubl.). Aerial photography and fieldwork have located extensive field systems and enclosures on the Magnesian Limestone outcrop (Roberts 2010), with several sites being well preserved within woodland (e.g. Ramm 1973); these appear to be largely of Iron Age and Roman date. Aerial photography followed 
up by geophysical survey (Steers 1995) indicates a sub-rectangular enclosure immediately north-east of Scabba Wood.

Earthworks within the wood include extensive north-south narrow ridge and furrow to the east of a sub-rectangular enclosure, with a smaller set of broader rigs to the west of the rock outcrop; terracing around the enclosure may represent fields from prehistoric farming (Chadwick and Robbins 1998). Some of these are similar to examples visible as cropmarks on the limestone to the north of the wood (Roberts 2010). The enclosure appears to sit within a block of prehistoric rectilinear fields, visible in LiDAR imagery as terraces, and in part overlain by the broad east-west rigs (Figure 3). The westernmost of the terraces is visible on the ground as a long bank, aligned north-south and running south from the Scabba Wood enclosure.

\section{Previous work}

In January 1992 the landowner, the late Mr. Morris, alerted South Yorkshire Archaeology Service to human bones unearthed by badgers at the rock overhang. Excavations revealed the poorly preserved partial and disarticulated remains of two individuals, a 20-30-year-old male and a 10-15-year-old child, and a few crumbs of prehistoric pottery (Chadwick 1992). One individual is dated to 3490-3140 BC at 95.4\% probability (UB-3629; $4590 \pm 30 \mathrm{BP}$ ), during the Middle Neolithic.

In 1996 the Doncaster Archaeological Group commenced excavations on the subrectangular enclosure $150 \mathrm{~m}$ south-west of the limestone outcrop (Figure 3). Trenches revealed that its wall was constructed with two parallel rows of large limestone slabs set on edge about $1.5 \mathrm{~m}$ apart, its core filled with limestone rubble surviving to $0.4 \mathrm{~m}$ high. On the enclosure's east side a slight and irregular ditch ran along the interior side of the wall. Small trenches within the enclosure's interior revealed a very shallow soil profile, containing sherds of Roman and prehistoric pottery and a fragment of a Millstone Grit saddle quern, on top of an extremely uneven surface of limestone blocks. 


\section{The 1997 and 1998 excavations}

Seven trenches (A, C, D, E, F, G, H) were cut across the enclosure bank, in two cases ( $\mathrm{F}$ and $\mathrm{H})$ to determine if an entrance was present (Figure 4). The other two trenches were placed to determine the survival of archaeological layers inside and outside (to the east of) the enclosure.

The rock shelter was investigated in 1998 with two trenches, P and Q, around its two western outcrops. The more southerly of these (Trench P) was where the 1992 excavation took place. In the northern trench (Trench Q) only the topsoil was removed to define the wall line. All soil from excavations at the rock shelter was sieved through a $10 \mathrm{~mm}$ mesh, although sampling for palaeoecological study was precluded by the shallow and heavily disturbed nature of the sediments.

\section{The enclosure (Figures 4-20)}

The enclosure is sub-rectangular, $26 \mathrm{~m}$ by $27 \mathrm{~m}$ overall, with rounded corners. The walls survive as an apparently continuous bank roughly $2 \mathrm{~m}$ across, with no obvious sign of any entrance, although a depression at the north-east corner leads out into a slight hollow way running past the site. In many places limestone rocks protrude from the bank, some of which were large and set upright as orthostats. They are visible on three sides of the enclosure and the bank is easily traceable on all sides. In places, the outer slope of the bank and possible exterior ditch are more easily seen and in others the interior slope and possible ditch are clearer. At some points, the slope of the bank is clear and stones protrude through the top of the bank. In other places only stones or a slight slope (on the east side) indicate the limits of the enclosure. This may derive from different modes of construction for different lengths of the bank, or it may simply be the result of differential erosion.

The interior of the enclosure is up to a metre lower than much of the land immediately surrounding it, suggesting that it lies within an excavated or eroded hollow. The profile in Trench $\mathrm{C}$, and the absence of cryoturbated limestone on top of 
the large blocks within the enclosure, suggests that the enclosure walls were constructed within an area previously excavated to form a hollowed terrace.

A broad bank runs from the enclosure at the south-west corner for about $50 \mathrm{~m}$, forming the boundary between two probable prehistoric terraced fields visible in LiDAR imagery (Figure 3); it is described here as a long bank.

\section{Trench A (Figures 7-8)}

Trench A appears to cut internal (108) and external (123) ditches. The upright stone slabs of the bank survive to an excavated height of at least $1 \mathrm{~m}$. Either the internal and external ditches were part of the same ditch, whose fill was overlain by the bank, or the enclosure wall was constructed after excavation of the hollow.

\section{Trench B (Figures 9-10)}

Trench B, in the centre of the enclosure, revealed a layer of cobbles (102) overlying two layers of rocks, the uppermost with large and angular rubble in an orange matrix (114) and the yellower lower layer (115) comprising very large but evidently humanly disturbed rocks with slag and animal bones.

\section{Trench C (Figures 11-12)}

In Trench $\mathrm{C}$ the enclosure bank consisted of small rubble set into the top of an earthen bank (101). The abrupt drop in the height of bedrock about $2 \mathrm{~m}$ north of the outer edge of the enclosure bank suggests that this was the northern limit of the hollowedout area that had stood prior to construction of the enclosure.

\section{Trench D (Figures 13-15)}

Trench D revealed the enclosure's wide and fairly low bank, inside of which was an apparent ditch of stone-free, orange-brown loam (103). The ditch's upper fills produced Roman finds including a fragment from a 3rd or 4th century colour-coated beaker and an AVCISSA-type brooch of c.AD 40-60 (see Figure 30). A similar fill (104) was found outside the bank but contained no Roman material. Inside the enclosure, a possible cob-bled area (112) was revealed. The enclosure bank consisted 
of orange-brown loam (121) with smallish stones set into its top. An earlier phase of construction was suggested by two parallel features of yellow-grey sand and stones (125 and 126) running along the line of the bank. These features are interpreted as the remains of 'robber' trenches into an earlier phase of stone construction (with inner and outer retaining 'walls') later replaced by an earthen bank.

\section{Trench E (Figure 16)}

Trench $\mathrm{E}$ was an unfinished excavation of the postulated inner and outer ditches.

\section{Trench F (Figure 17)}

Trench F lay at the south-west corner of the enclosure bank where it meets the long bank that extends southwards from the enclosure. The long bank's fill (106) is largely stone-free and contains a number of bone fragments, struck flints and a few sherds of prehistoric pottery. Below these sherds, a small assemblage of poorly struck flint flakes was recovered, including a Middle/Late Neolithic chisel arrowhead. The mound overlies the enclosure's earthen bank (120) with stones set into the top. Excavation of layer 120 was not completed but yellow-grey gritty deposits (127 and 128), similar to those found in Trench D, were encountered.

\section{Trench G (Figures 18-19)}

Trench $\mathrm{G}$ was placed to examine the western length of the enclosure bank/wall. Removal of the topsoil revealed the upper levels of a stone bank with orthostats.

\section{Trench H (Figure 20)}

Trench $\mathrm{H}$, at a possible north-east entrance to the enclosure, revealed a spread of medium-sized rocks and a number of orthostats.

\section{Summary}

The enclosure's bank is constructed of stones and earth, and may well have been continued upwards in turf in order to provide an effective barrier. Although it shows no sign of any entrance, a depression at the north-east corner leads to a slight hollow 
way running past the site. Whether this hollow way was contemporary with, or later than the construction and use of the enclosure is unknown. The interior of the enclosure is lower than much of the land immediately surrounding it, suggesting that the enclosure walls were constructed within an area previously excavated to form a hollowed terrace.

The western and eastern lengths of the enclosure's perimeter appear to be formed by a large wall of upright stone slabs which retain an earthen and stone core. Surface remains suggest that this was also the case along the unexcavated northern side.

Along the southern side this construction method may also have been used but was perhaps truncated and overlain by a later earthen bank. Excavation of those parts of Trenches D, E and F beyond the southern line of the enclosure showed the accumulation of a deep deposit of sediment (especially in the south-west corner where the long bank meets the enclosure bank). This deposit partly overlies the enclosure's southern bank and is similar to the northern bank of the 'hollow way' running along the north side of the enclosure (excavated in Trench C). These two earthen banks may be related to each other but have little or nothing to do with the enclosure proper.

\section{Dating evidence for the enclosure}

The excavation did not provide unambiguous evidence for the date of construction of the enclosure or excavation of the terrace feature. The AVCISSA-type brooch (Figure 30) suggests occupation in the mid to late first century AD. This and the few sherds of mostly Roman pottery come from deposits late in the stratigraphic sequence and so do not date the construction of the enclosure. Coarse hand-made reduced-fired pottery (Figure 29) from the earthen long bank (and its side ditches) along the southern side of the enclosure may be Iron Age in date (see below). Among the prehistoric struck flints is a chisel arrowhead of a style dating to the Middle/Late Neolithic (c.3400$2600 \mathrm{BC})$. 


\section{Conclusion}

Only a handful of pottery sherds and a few worked flints were recovered from the whole of the enclosure area. The Roman brooch and pottery were certainly deposited sometime alter the enclosure's construction and their secondary contexts indicate that its origins pre-date the Roman conquest of the region.

Broadly similar enclosed settlements have been recognised in South Yorkshire, mostly as cropmarks (Roberts 2010), but those in Edlington Wood, south of the river Don (Corder 1951; Ramm 1973), survive as similar walled constructions with 'scooped' interiors. Some of these were occupied during the Roman period but the scarcity of Iron Age pottery in South Yorkshire makes identification of pre-Roman occupation difficult (Davies et al. 1998). The way in which Roman road systems cut across blocks of pre-existing fields (Riley 1980; Roberts 2010: Figure 79), however, clearly shows their earlier origin. On Balby Carr, south of Doncaster, ditches associated with a brickwork field system were already being allowed to silt up by $c$. $200 \mathrm{BC}$ (Jones 2007), and it is tempting to see the irregular enclosures as part of an earlier phase of settlement on the limestone, parts of which were incorporated into the later systems. Pollen evidence from further east, on Hatfield and Thorne Moors shows an essentially cleared landscape by the early Iron Age (Smith 2002), into which sites like Scabba Wood might fit.

\section{The rock shelter}

Two trenches (P and Q) were opened against the face of the $16 \mathrm{~m}$-long limestone outcrop (Figure 21), the westernmost of five substantial outcrops in this northern part of Scabba Wood. Trench P was located around and to the north of the findspot of the Middle Neolithic human bones excavated in 1992 (Chadwick 1992). Trench Q was opened against the rock face north of Trench P. A $1 \mathrm{~m} \times 1 \mathrm{~m}$ test pit (Trench R) on top of the outcrop revealed no archaeological deposits or finds. 


\section{Trench P (Figures 22-27)}

The trench of $44 \mathrm{sq} . \mathrm{m}$ was positioned against the $1.8 \mathrm{~m}$ high rock face and included a large boulder formerly attached to the outcrop. The cleft between boulder and rock face, excavated to $0.8 \mathrm{~m}$ deep, contained a sequence of layers with mixed finds from many different periods.

The lowest layer excavated was a compacted orange-brown loam (807), containing Neolithic flints and Roman pottery. At the base of layer 807, a small concentration of fire-damaged stones and burnt bone may be the remnants of a disturbed hearth. Finds from 807 included a segment of a rotary quern (1413), a piece of a cannel coal artefact, possibly an armlet (1575), three Roman coins (1441, 1450 and 1460) and a human molar (1573).

Above layer 807 was a layer (803) of loose light orange loam; layer 804 (unexcavated) forms the western part of 803 and is more orange with greater clay content. Badger claws and bones attest to considerable disturbance of layer 803. Finds from layer 803 included a flake from a Group VI (Langdale) Neolithic stone axe (1400), and one possible and three certain fragments of earlier Neolithic leaf-shaped arrowheads. There was also a plain Early Bronze Age body sherd (1250), deriving from a thick-walled vessel tempered with grog and bone; this sherd may conceivably have come from a cremation burial since fragments of cremated human bone were recovered from a metre away to its west. Amongst the Iron Age and Roman pottery, there was a single sherd (1447) from the ovolo of form 37 Eastern Gaulish samian bowl (AD 160-220) and comminuted sherds from at least four locally produced grey ware jars. Also from 807 was a hemispherical silvered button (1403) of likely 18thcentury date.

Finds from the topsoil (800) included human remains from a young juvenile: a heavily worn deciduous molar (1216) and an unerupted molar (1220).

\section{The overhang within the large boulder}

Under the western part of the large boulder, a substantial overhang had been almost entirely filled with deposits. The lowest excavated was loose soil (808) containing struck flints including a fragment of a Neolithic leaf-shaped arrowhead (1505), an 
Anglo-Scandinavian pendant hone (1532), Roman pottery, two human teeth (1446 and 1519) and animal bone. Above layer 808 was layer 803 and topsoil (800).

\section{The site of the 1992 burials beneath the overhang}

The Middle Neolithic burials were thought to have been placed within a stone cistlike structure beneath the overhang (Chadwick 1992). Renewed excavation here revealed a sequence of deposits starting with two sterile layers: 814, a deposit of rubble within an orange-red matrix, and 815 (Chadwick's layer 105), a layer of weathered limestone occurring as a yellow silt restricted to the area beneath the overhang. Above 814, layer 805 equates to Chadwick's layer 104 and contained a single human phalanx (1409), the proximal end of a human metacarpal (1448) and a small piece of probable human scapula (1494). Worked flints from 805 consisted of a serrated flake (1511) and a waste flake (1495). Part of the cist-like structure survived as a single-coursed line of stones (feature 806) forming its west wall. Above and south-east of layer 805 , layer 802 contained a human phalanx (1258) and a rim sherd of Roman greyware (1410).

\section{The cleft between the rock face and the large boulder}

The large boulder clearly broke away from the rock face well before the Neolithic since the gap was filled with Neolithic and later debris. The lowest layer, unexcavated, was a densely packed matrix of eroded limestone. Above this, a $0.26 \mathrm{~m}$ deep layer of rubble within a red-brown soil matrix (812) produced 2 large sherds of grog-tempered plain thick-walled Early Bronze Age pottery (1510 and 1530), a small piece of iron (1537), two flint flakes, five Roman sherds, twenty mammal bones, seven burnt/cremated bone fragments and seven human bone fragments and teeth deriving from a minimum of two individuals. A partial phalanx (1536) and a skull fragment (1543) derive from a juvenile whilst a tooth (1580) a phalanx (1581), and three of the four mandible fragments $(1561,1579,1580$ and 1582) come from an adult. Two of the latter (1561 and 1579) conjoin and form that part of the mandible which is present in one of the individuals under the nearby overhang (see Rega 1992). 
Above layer 812 lay a localised deposit of brown soil (811) lying within a slight cavity on the eastern side of the cleft. It contained no cultural material and was covered by layers of rubble (801) and topsoil (800).

\section{Trench $Q$}

Trench Q covers an area of 18 sq. m. Under the deep overhang in this northern part of the rock face there are large boulders and deposits of soil and rubble, which extend west of the overhang to form a facade of boulders and stones east of an open area. Only the topsoil (900) and recently deposited rubble within this uppermost humic layer were removed, to a depth of between $0.15 \mathrm{~m}$ and $0.3 \mathrm{~m}$. Finds included modern material, Roman sherds, a retouched flint flake, and a fragment of adult human skull (1311).

\section{Summary of the rock shelter sequence}

The Earlier Neolithic period, contemporary with the burials, is represented by five fragments of leaf-shaped arrowheads (two of them conjoining), a blade struck from a broken Group VI stone axe from Langdale in Cumbria, and a small narrow-blade flint assemblage. A piece of a saddle quern could also date to this period. Some of the seventeen fragments of human bones and teeth most likely belonged to the two Middle Neolithic individuals but they also derive from possibly two more individuals - an older adult and an 8-9-year-old child. An Early Bronze Age sherd, together with pieces of cremated bone scattered around the area of the boulder, could derive from the disturbed remains of one or more cremation burials. Six possible Iron Age sherds suggest activity here in the 1st millennium BC. Roman material was more common than in the enclosure. Together with five coins of the late 3rd-mid 4th centuries AD, there were about fifty sherds of Roman pottery including small eroded sherds of at least four South Yorkshire coarse ware jars and a sherd of East Gaulish samian (AD 160-220). The Roman pottery and coins range over at least two centuries between c. AD 150 and c. AD 350+. The polished cannel coal fragment is also likely to be 
Roman. An Anglo-Scandinavian pendant hone and a Post-Medieval silvered button were the only other traces of activity prior to the 20th century.

\section{The finds}

Finds from Scabba Wood enclosure and rock shelter included Roman coins and pottery, prehistoric pottery, worked flint and animal bones. In addition, the rock shelter produced disarticulated human bones. All finds, except the prehistoric pottery, were returned to the owners and after the death of Mr. Morris, much of it was deposited in Doncaster Museum, although a number of important items, including the brooch, colour-coated sherds from the enclosure and the medieval hone, do not appear to have been included and they may be lost. Thus there are no detailed finds reports for some items.

\section{The human remains from the rock shelter (By Andrew Chamberlain and Pia}

\section{Nystrom)}

The human skeletal remains from the 1998 excavation were examined and compared with material recovered from the same site in 1992. The combined assemblage represents a minimum of three, possibly four individuals. Individual A is represented only by finds in the 1992 assemblage. Individual B is a juvenile aged 12 to 15 years and of undetermined sex, represented by finds of two teeth in 1992, and from teeth recovered in 1998 from contexts 800, 807 and 808. Individual $\mathrm{C}$ is an older adult, represented by teeth from contexts 807 and 812 in 1998, and possibly represented by a single foot bone in the 1992 series. Two teeth from context 800, provisionally assigned to Individual B, alternatively might be interpreted as belonging to a younger child, aged eight or nine years and designated Individual D. Given the variable locations of the remains, even with substantial badger disturbance, the total number of individuals may, in fact, be as many as seven. That most of these fragments are teeth or phalanges suggests that soil acidity might have largely destroyed most of the less robust remains. Alternatively, the recovery of fragments from deposits that have all 
been subject to considerable disturbance may signal the survival of more complete remains within layers that have not been turned over by badgers and foxes. A further two individuals (Individuals $\mathrm{H}$ and I) may be represented by groups of burnt bones in close spatial association to fragments of Early Bronze Age pottery.

1992 Finds. Human skeletal remains excavated by South Yorkshire Archaeology Services in 1992 were analysed by Elizabeth Rega, who determined that a minimum of two individuals were present in the assemblage (Rega 1992). An adult male was represented by a fragmentary skeleton including some upper and lower teeth but missing its cranium (Individual A). Dental attrition indicates that Individual A was aged 20 to 30 years, and a fragment of the right pubis, not identified in Rega's (1992) inventory, supports this younger age assignment. The presence of additional individuals in the 1992 finds was indicated by recovery of two adult left first metatarsals (one may represent the adult identified as Individual C), and an upper canine and lower premolar that have much less occlusal wear than Individual A. These teeth from the 1992 excavation are assigned to a sub-adult designated as Individual B. Assuming similar rates of dental wear to that documented in the adult skeleton, Individual B is estimated to have been between 12 and 15 years, younger than the adult age assigned by Rega (1992).

1998 Finds. The 1998 finds of human skeletal material are listed in Table 1. Of these finds, five teeth have either not completed their development, or show occlusal wear consistent with a sub-adult age, and are conservatively assigned here to Individual B. Specimen 1216 is a heavily worn lower deciduous second molar: this tooth is normally shed by the time the individual is 13 years old, but the degree of resorption of the roots might indicate a younger age around 9 years, in which case this specimen would provide evidence of a second sub-adult skeleton being present (Individual D). Specimen 1220 is a lower second or third molar with root development consistent either with a 14-year old (Individual B, if the tooth is an M2) or an 8- to 9-year old (Individual D, if the tooth is an M3). 
Specimen 1573 is a lower first molar with occlusal wear indicating an age of around 12 years (Individual B): this tooth has an interproximal wear facet which may match that of 1216, which discounts the likelihood of the latter specimen being assigned to Individual D. Specimen 1446 is a lightly worn lower canine with occlusal wear that is identical to that seen in the upper canine of Individual B. Specimen 1519 is an upper central incisor with occlusal wear matching that observed in the other anterior teeth of Individual B.

Two adult teeth belong to an older adult, provisionally assigned to Individual C. The upper premolar (unnumbered from context 807 ) is heavily worn and must therefore be considerably older than Individual A. The lower first molar (1580) has occlusal wear indicating an age of 30 to 40 years. The mandible fragments from context 812 may also belong to Individual $\mathrm{C}$ as they are likely to represent an adult individual yet cannot belong to Individual A. Other finds of human remains from the 1998 excavation are undiagnostic and cannot be placed securely into an age category; hence have not been assigned to recognised individuals.

Individuals $A$ and $B$. These were recovered in 1992 and consist of an adult male aged 20 to 30 (Individual A) and a juvenile aged 12 to 15 (Chadwick 1992; Rega (1992) aged the individuals as 30 to 40 and 20 to 30 , respectively). On the basis of a single radiocarbon date (UB-3629; $4590 \pm 30 \mathrm{BP}$ ), they may be assigned to 3493-3143 cal BC (at 95.4\% probability) during the Middle Neolithic (c.3400-3000 cal BC). In 1998 three more bone fragments were recovered: a manual middle phalanx (1409), the proximal end of a second right metacarpal (1448) and the acromial process of a probable scapula (1494). In addition, the manual proximal phalanx (1258) from 802 probably derives from these individuals.

Individual C. A heavily worn mandibular right M1 (1580) suggests the presence in the cleft of remains of an adult over 40 years old. Conjoining right-side mandible fragments (1561 and 1579), another mandible fragment (1582) and a manual proximal phalanx (1581) also belong to an adult. However, these may derive from Individual B. 
Individual $D$. This is represented by a heavily worn deciduous molar (1216) and an unerupted permanent molar (mandibular M2) (1220) found at E2166.60 N2179.70. These provide an approximate age of 6 to 9 years old for this juvenile. The two teeth were found immediately in front of the stone facade.

Individual E. A mandibular left canine (1446) and a maxillary first right incisor (1519), both relatively unabraded, derive from a young adult in their early teens. Both teeth come from the cavity beneath the overhang on the west side of the large boulder. A mandibular left M2 (1573) in 807, less than $2 \mathrm{~m}$ away, and an abraded maxillary premolar, also from 807, may derive from the same individual although age is tentatively estimated as mid-twenties.

Individual $F$. A manual middle phalanx (1536) and a cranial fragment from the frontal process of zygomatic bone on the left side (1543) from 812, within the cleft, indicate the presence of a second juvenile. However, they may come from Individual B.

Individual $G$. The cranial fragment of an adult's right zygomatic bone (1311) from 900 in Trench Q is likely to derive from another individual, given its distance from the other remains.

Individual $H$. The burnt bones (1525, 1534, 1555, 1559, 1560, 1564, 1565 and 1582), in association with Early Bronze Age sherds (1510 and 1530) in layer 812, hint at the possibility of a disturbed cremation burial within the cleft. A sherd (1250) from a second Early Bronze Age vessel under the overhang on the west side of the large boulder could derive from a second in-urned cremation burial.

\section{The animal bones from the rock shelter (By Pat Collins)}

Much of the bone material is eroded, probably after deposition in the soil since the bones often look etched rather than weathered. Very few traces of gnawing and none 
of butchery were found, no doubt the result of this erosion. Most of the fragments were small and unidentifiable, but 88 specimens were identified to species: horse, cow (for non-dental specimens this could include red deer), pig, sheep/goat, fox, badger and domestic fowl. Some canid bones could not be identified further than dog/fox. The presence of badger and possibly fox suggests that the site may be disturbed by burrowing, a process confirmed by the stratigraphic evidence. The presence of smaller taxa may be the result of their being the prey of these animals. Most of the unidentified smaller bones seem to be of rabbit.

\section{The worked flint (By B. Chan)}

The assemblage consists of sixty-four pieces of flaked stone (Figure 28) derived from thirteen contexts with three of the pieces unstratified. The majority of the material (77\%) came from the area of the rock shelter and $19 \%$ came from the enclosure.

The rock shelter. The debitage from the rock shelter consisted mainly of flakes, blades, bladelets and a smaller number of chips, irregular waste and two cores. Alongside this material was a serrated flake, a miscellaneous scraper, a utilised/edgedamaged flake, six miscellaneous retouched flakes and five fragments of arrowheads $(1462,1464,1505,1506,1517)$. Four of these fragments are sufficiently complete to be identified as leaf-shaped arrowheads and two of these fragments (1506 and 1517) refit to form a complete arrowhead. The surfaces of the break on the refitting segments are heavily patinated, indicating that the break happened in antiquity. The fifth arrowhead fragment is too small to identify with certainty, but it is also possibly part of a leaf-shaped arrowhead.

In total, the assemblage from the rock shelter consisted of forty-nine pieces, the majority of which came from Trench P where contexts 807, 803, 800 and 808 contained eighteen, fifteen, six and four pieces, respectively. The serrated flake came from context 805, whilst four fragments of leaf-shaped arrowhead came from 807 and the other (1505) from 808. 
As a whole, the assemblage has a notably high proportion of both formal tools and retouched flakes (Table 2) with a correspondingly low proportion of flakes and blades. Despite this, blades and bladelets are well-represented and make up $16 \%$ of the assemblage from the rock shelter. The blades themselves have signs of both platform preparation (trim-ming) and of having been removed from an opposed platform core. Both techniques are associated with the careful removal of blades from relatively well-prepared cores, which suggests that the assemblage is derived from earlier Neolithic activity.

The enclosure and unstratified material. The assemblage from the area of the enclosure is much smaller than that from the rock shelter and includes six flakes, a blade, two chip, two pieces of irregular waste and a chisel arrowhead. All but one of these came from Trench F and eight of the twelve artefacts, including the arrowhead, came from context 106. In addition to the excavated material, three unstratified artefacts - a blade, a single platform flake core and a retouched flake - were found. The blade and the core came from the surface of a field at SE529019 and the retouched flake was found on the surface of a nearby track.

Assemblage chronology. The presence of leaf-shaped arrowheads, a serrated flake and the proportion of blades within the assemblage from the rock shelter all suggest that this material is earlier Neolithic in date. There is no diagnostically later material. The assemblage from the enclosure includes a chisel arrowhead, which suggests a broadly Middle Neolithic date.

Raw material. Despite the relatively small size of the assemblage, six different types of raw material were identified (Table 3). The most common was chalk-derived flint (85\% of the assemblage) probably from either the Yorkshire or Lincolnshire Wolds. The rest of the raw materials were represented by a small number of artefacts and included a blade flaked from a ground stone axe of Group VI Langdale type (Figure 28: 1400). The butt of the blade was unpolished, but part of its dorsal surface was 
formed from the polished surface of the axe. This indicates that the axe was already broken prior to removal of the blade.

Discussion. The majority of the diagnostic elements within the assemblage are earlier Neolithic in date. The material is also characterised by a wide variety of raw materials and high proportions of both formal tools and retouched flakes. This probably reflects both the distance of the site from a primary source of flint and the particular character of the activities that took place around the rock shelter. In this respect, the high proportion of tools and retouched blades suggests that raw material usage was maximised and/or that these items were brought to the site already prepared.

It is notable that all the leaf-shaped arrowheads are broken, and depending on the condition in which the human remains arrived at the site, it is possible that these entered the site lodged in corpses, rather than having been brought to the site for purposeful deposition. Such a possibility has been discussed by Mercer $(1999,149$ 150 ), who has noted the substantial number of leaf-shaped arrowheads found with human remains in the British Neolithic.

\section{The prehistoric pottery (By C.G. Cumberpatch)}

The assemblage consisted of thirty abraded sherds of pottery representing a maximum of twenty-one vessels and weighing 163 grams (Table 4). Type names used in this analysis are derived from Didsbury's scheme for later prehistoric pottery in East and north-eastern Yorkshire (e.g. Didsbury 2009). This scheme is broadly comparable to Rigby's description of pottery from East Yorkshire (Rigby 2004). There is a degree of grouping in terms of fabric, although there are differences within each group (the ' $\mathrm{H}$ ' prefix in Table 4 denotes hand-made pottery). The groups proposed are as follows:

Group 1. Rock tempered wares; $c f$ East Yorkshire type. All from context 807 (1473, $1465,1436,1445,1499,1574)$

Group 2. Orange fabrics with distinctive angular rock fragments; probably Early Bronze Age. All from contexts 812, 807 and 803 (1510, 1429, 1250, 1530)

Group 3. Fine quartz sand tempered fabrics; $c f$ East Yorkshire type. All from contexts 807, 106 and 900 (1490, 1568 [x2], 1005, 1309, 1512) 
Group 4. Vesicular fabric with fine quartz; $c f$ East Yorkshire types (H2/H5) From context 807 (1461)

Comparison with known types suggests that Groups 1, 3 and 4 are of later prehistoric date similar to those known from East Yorkshire (cf. Rigby 2004), with a broad date range from $c .700 \mathrm{BC}$ to the late Roman period (and possibly later).

The origin of the individual vessels represented by the sherds is unclear. While it is possible that some were imports from eastern Yorkshire where pottery use in the later prehistoric period was far more common than it was in the virtually aceramic communities of south-west Yorkshire, the ubiquity of quartz sand as a tempering material means that it is likely to be extremely difficult to identify a specific source for individual vessels (Table 5).

Typologically the sherds are generally undiagnostic. One possible and two definite rim sherds (Figure 29, 1461, 1429 and 1530) were identified (contexts 807 and 812) but none was distinctive and two are typical of the open-mouthed, shoulderless jars with plain rims present in Yorkshire throughout the later prehistoric and Roman periods. One sherd bears definite fingernail impressions (Figure 29: 1500) and another two appear to have similar marks (1490 and 1512, both from context 807). North of the Humber, decorated pottery of later prehistoric date is rare and no specific parallels for these sherds are known to the author. Sherds of quartz-tempered ware with fingernail impressions and a distinctive 'pinch-and-twist' decoration are known from Scarborough Castle (Challis and Harding 1975, Figures 42 and 44).

Chronology. Using later prehistoric pottery to calibrate stratigraphic sequences or to provide spot dates for individual features or deposits has proved to be a difficult task (cf. Rigby 2004). The only possible conclusion is that while Groups 1, 3 and 4, as defined above, have all the characteristics of pottery of later prehistoric type or Roman-period native tradition, it is not possible to be more precise about their dating. The pottery in Group 2 is likely to be of earlier prehistoric date, probably from the Early Bronze Age. 


\section{Roman coins from the rock shelter (By Paul Buckland)}

Five Roman coins were found in the area of the rock shelter. Three of these (1441, 1450 and 1460) were excavated in Trench $P$ and two (1205 and 1206) were found by metal detecting in an earlier investigation. Unfortunately these were not available for more detailed examination.

\section{Coin 1460}

Context 807

Worn Weight $2.5 \mathrm{~g} \quad \varnothing=17-19 \mathrm{~mm}$ (AE3)

Obverse: $\quad$ Laureate head facing rt. CRIS[P]VS [N]O[BIL C]

Reverse: Altar

AD 320-326.

$$
\begin{aligned}
& \mathrm{VOT}[\mathrm{I}] \mathrm{S}[\mathrm{XX}] \\
& \text { In exergue PL[O]N (London) }
\end{aligned}
$$

[BEAT. TRA]NQLITAS

\section{Coin 1450}

Context 807

FAIR/UNWORN Weight $2.2 \mathrm{~g} \quad \varnothing=17 \mathrm{~mm}$ (AE3)

Obverse: $\quad$ Diademed, draped and cuirassed bust facing rt D N CONSTAN S P F AVG

Reverse: $\quad$ Soldier spearing falling enemy [F]EL. TEM[P] . REPARATIO

AD 346-350 In exergue SLG (Lyons)

\section{Coin 1441}

Context 807

WORN

Weight $2.0 \mathrm{~g}$

$\varnothing=19-20 \mathrm{~mm}$

Obverse:

Bust with radiate crown

$$
\text { [illegible] }
$$

Reverse: standing figure ?

$$
\text { [illegible] }
$$

The coin is a late third century barbarous radiate.

\section{Coin 1205}

Context 800

House of Constantine

Reverse: $\quad$ Romulus and Remus

The coin probably dates to the AD 330s. Found by a metal detector in 1991 . 


\section{Coin 1206}

Context 800

Obverse: illegible

Reverse: $\quad$ Soldiers either side of a shield (GLORIA EXERCITUS)

4th C, after AD 330. Found by a metal detector in 1991.

\section{Brooch (Figures 30 and 31)}

Copper-alloy AVCISSA-type brooch, with the name ATGIVIOS stamped across the base of the head. The bow has a beaded central rib and terminates in a grooved knob below the catchplate. Compared with the more widespread ones stamped by AVCISSA and unstamped examples, ATGIVIOS, and variants on the name from different dies, are rare with finds in England from Colchester, Alcester, and Wroxeter (2) (Collingwood and Wright 1991; Figures 2421.2-4). An unstamped example of the same form has been recovered by metal detector close to the Claudio-Neronian vexillation fortress site at Rossington Bridge (O'Connor 2001; Figure 55, 2), and there is a further example from Dragonby in North Lincolnshire (May 1996; Figure $11,6.66)$. Imported from the Continent, Mackreth $(2011,132)$ dates the type to the immediately post-Conquest to Neronian period (AD 43-60/65). There are a few other finds beyond the pre-Flavian frontier, including ones from Rudston, Thornton-le-Dale and Aldborough (Stead 1971).

\section{Cannel coal armlet fragment.}

1. A flake, $36 \mathrm{~mm}$ by $23 \mathrm{~mm}$ and only $4 \mathrm{~mm}$ in maximum thickness, has a smoothly rounded, finely polished outer surface and an irregular to sub-conchoidally fractured inner surface; the edge fracture shows traces of fine lamination indicating that the piece is worked from a dull black cannel coal rather than jet. The shape and fine polish suggest that the flake comes from an item of jewellery, perhaps a massive annular armlet as the example, probably from York, figured by Allason-Jones (1996, No. 87). Whilst the York examples are of jet, she notes (idem, 33) examples from Cologne made from 'shale'.

(1575) from the Rock shelter, context [807]. 


\section{Palette fragment}

1. The corner of a roughly finished block, possibly a cosmetic palette, $40 \mathrm{~mm}$ by 30 $\mathrm{mm}$ and $9 \mathrm{~mm}$ thick. The edges are rounded and knife trimming marks are still evident on three surfaces. The basal fractures are largely planar and there is slight trace of lamination, suggesting a similar raw material to the armlet. Although Allason-Jones (1996) does not include any palettes from York, she does refer (idem No. 338) to a block of cannel coal from the Mount, $99 \mathrm{~mm}$ by $49 \mathrm{~mm}$, of unspecified thickness.

(1016) from the Enclosure, context [110]; a small chip from context [106] is probably from the same artefact.

\section{Hone}

1. Although only briefly seen and subsequently lost with other items with the demise of the landowner, the small hone, $\sim 50 \mathrm{~mm}$ long by $\sim 10 \mathrm{~mm}$ wide and $<10 \mathrm{~mm}$ thick, pierced at one end, in a dark blue-grey rock probably a phyllite, belongs to a group largely of Norwegian origin (but see discussion by Gaunt in Mainman and Rogers $2000,2485)$. A ninth to twelfth century date is probable (op. cit.).

A surface find in the vicinity of the Rock Shelter.

\section{Roman Pottery}

Several sherds, found together, of a 'Castor box' in a very light grey/white fabric with brown to orange colour coat. The type was produced in the Nene Valley from the late second to late fourth century (Perrin 1999, 98-99), as well as at Swanpool, near Lincoln (cf. Webster and Booth 1947, Figure 3, C5). The Scabba Wood vessel appears similar to the latter products of the late fourth century.

From the enclosure ditch (not in Doncaster Museum).

(1) Rim sherd and at least two body sherds from a large jar in a gritty dark grey fabric with irregular black surface. Although insufficient was found to reconstruct the full form of the rim, the vessel is similar to Swanpool Type H (Webster and Booth 1947; Darling 1977) and is likely to be mid- to late fourth century. (1200) Context 800, from the Rock Shelter. 


\section{Discussion}

\section{Neolithic funerary deposits in rock shelters and caves}

The Scabba Wood rock shelter burial is one of a number of such deposits known from the Lower Magnesian Limestone in Yorkshire and Nottinghamshire. Over fifty similar Neolithic burials or deposits of human remains have been found in England, indicating that cave or rock shelter burial was a substantial if underestimated component of Neolithic funerary rites (Chamberlain 1996, 2007; Chamberlain and Williams 1998). Whilst earlier Neolithic rock shelter burial deposits are known from Yorkshire (Leach 2006), the best-known comparisons are the Church Dale rock shelter near Monyash in Derbyshire (Clark 1953) and Gop Cave in Flintshire (Piggott 1954, 307) with human remains in various stages of disarticulation and Middle Neolithic Peterborough Ware.

Scabba Wood rock shelter's topographic setting provides a good example of how Neolithic communities appropriated natural features (Bradley 1993, 2000). The outcrop's appearance, at the head of a small valley, potentially recalls the entrance of a Neolithic chambered tomb between hornworks. Secondly, the outcrop lies within view of the King Hengist Rein long barrow, $150 \mathrm{~m}$ to the north on the level limestone plateau, suggesting that both may have formed part of a Neolithic ceremonial nucleus that extended upstream to the High Melton long barrows (Cockrell 2016).

\section{The prehistoric enclosure and field system}

Most enclosures on the Sherwood Sandstone and Magnesian Limestone are associated with the 'brickwork' field systems (Riley 1980; Roberts 2010), such as Gunhills, Armthorpe, east of Doncaster (Richardson 2008), and Dunstan's Clump (Garton 1987) and Scrooby Top in north Nottinghamshire (Davies et al. 1998; see also Chadwick 1997, 2008). These appear to have been constructed in the early first century $\mathrm{AD}$, probably in association with the long, parallel field systems that characterise the brickwork pattern, although the date from the Balby Carr site would suggest that at least some of these are substantially earlier (Jones 2007), as is the case with the Early Iron Age 'marsh fort' at Sutton Common (Whiting 1936; Pearson and 
Sydes 1997; Van de Noort, Chapman, and Collis 2007). The rectangular enclo-sure north-east of Scabba Wood (Steers 1995) may well belong to the brickwork pattern of the first century AD.

Two cropmark-detected enclosures which may conceivably date to the Middle-Late Iron Age lie immediately north of Scabba Wood, the western being an irregular ovalshaped enclosure and the other a west-facing probably sub-rectangular enclosure with possibly associated field boundaries. To the south of Scabba Wood, a similar stonewalled enclosure is known at Scratta Wood, Scarcliffe, near Worksop (White 1966). The apparently scooped-out interior seen at Scabba Wood is also apparent on some of the Edlington Wood sites (Ramm 1973). Further afield, Jobey (1962) has drawn attention to 'scooped enclosures' in Northumberland, although these often contain hut bases. A possible ethnographic parallel for such scooped-out interiors can be drawn with domestic stock enclosures (manyatta) of the Maasai in northern Tanzania where dung and dust dry out and blow away to leave a dished depression within rough stone walls topped by a thorn fence. Sutton [1986] has drawn attention to similar preMaasai features in Kenya, known as Sirikwa holes.

The near-completely aceramic nature of South Yorkshire's Iron Age and the acidity of the loessic soils that overlie the limestone bedrock make identification of sites difficult. The adjacent Pot Ridings Wood has produced a Late Iron Age chape (Buckland 1986: 5-6). Such sites probably continued into the Roman period; Pot Ridings Wood and Marr Thick enclosure to the north as well as Edlington Wood (Corder 1951; Ramm 1973) have produced Roman metalwork and coin hoards (Buckland 1986). Dates of final abandon-ment are difficult to assess since the postRoman period shows a similar paucity of finds. The colour-coated vessel and lidseated jar from Scabba Wood, if late Swanpool products, suggest occupation at least into the late fourth century, a date supported by the coins of the House of Constantine from the site.

The Scabba Wood enclosure may be a rare survivor of what was once a common type of later prehistoric construction, spared from destruction by subsequent agricultural activity. Yet, there are problematic observations that are unexplained. Why is there an internal ditch? Why is the surface of the enclosure so uneven and 
apparently without inserted features? Why is there no certain entrance? Another possible interpretation of the enclosure is that it was constructed at a much earlier date. The form of wall construction and the dimensions of the enclosure are not entirely dissimilar from the embanked stone 'circle' of Barbrook II, a Late Neolithic/Early Bronze Age ceremonial monument on the gritstone of the Dark Peak (Barnatt 1990, 55-7). There remains the possibility that the Scabba Wood enclosure is a form of embanked stone ceremonial monument, re-used in the Late Iron Age and Roman periods. 


\section{Acknowledgements}

This work would not have been possible without the permission and support of the landowner, the late Mr. Morris. We thank the former Doncaster group of the Yorkshire Archaeological Society, particularly the late Ian Stead, Doug Croft and Andrew Steers. Ray Stables provided aerial photographic expertise and Janet Fletcher fed the team. The students were Victoria Ann Tomalin, J March, Liz Watts, Charlotte Dawson, Amy Dean, Allison Blanchard, Duncan Sayer, Lesley Richmond, James Gerrard, Paul Jeffries, Pat Driscoll, Pat Stuart, Neil Dransfield, Michele Forte, Rik Legge, Abby Guinness, Alastair Chitham, Shani Oates, Becky Morphy, Adam Daubney, James Buse, Harriet Foster, Richard Chatterton, Matthew Walsham, Chris Baker, Gillian Worrall, Tamsin Helliwell, Alex MacDonald, Elaine Bestwick, Tony Swiss, Paul Williamson, Carey-Louisa Maguire, Marie Dickerson, Ian Mylrea, Jacky Roebuck, Jacky Worrall, Alan North and Philip Harrison. A fuller version of this report is lodged with South Yorkshire HER. Illustrations were drawn by Irene Deluis (Figures 2, 3, 6, 8, 12, 14, 15, 17-19, 21-23, 26-31) and Colin Merrony (Figure 1). Photographs were taken by Paul Buckland, Mike Parker Pearson and Ray Stables, and the processing of the Lidar data was undertaken by Tim Prosser. The authors are grateful to Peter Robinson at Doncaster Museum for assistance with the finds and the archiving of the site records. 


\section{References}

Allason-Jones, L. 1996. Roman Jet in the Yorkshire Museum. York: Yorkshire Museum.

Barnatt, J. 1990. The Henges, Stone Circles and Ringcairns of the Peak District. Sheffield: Department of Archaeology and Prehistory, University of Sheffield.

Bradley, R. 1993. Altering the Earth. Edinburgh: Society of Antiquaries of Scotland.

Bradley, R. 2000. The Archaeology of Natural Places. London: Routledge.

Buckland, P. C. 1986. Roman South Yorkshire: A Source Book. Sheffield: Department of Archaeology and Prehistory, University of Sheffield.

Chadwick, A. M. 1992. “The Rock Shelter at Scabba Wood.” In Archaeology in South Yorkshire 1991-1992, edited by M. J. Francis, C. Cumberpatch, and S. P. Whiteley, 78-83. Sheffield: South Yorkshire Archaeology Service.

Chadwick, A. M. 1997. "Towards a Social Archaeology of Later Prehistoric and Romano-British Field Systems in South Yorkshire, West Yorkshire and Nottinghamshire." Assemblage 2. Sheffield: Department of Archaeology and Prehistory, University of Sheffield. http://www.assemblage.group. shef.ac.uk/2/2chad.html.

Chadwick, A. M. 2008. "Fields for Discourse: Landscape and Materialities of Being in South and West Yorkshire and Nottinghamshire during the Iron Age and Romano-British Periods. a Study of People and Place." Unpublished PhD thesis, University of Wales, Newport. http://independent. academia.edu/AdrianChadwick/Books/166556/.

Chadwick, A. M., and G. Robbins. 1998. Scabba Wood, Sprotborough, South Yorkshire: Archaeological Survey 1998. Sheffield: Department of Archaeology and Prehistory, University of Sheffield. Unpublished report.

Challis, A. J., and D. W. Harding. 1975. Later Prehistory from the Trent to the Tyne. British Archaeological Reports British Series 20. Oxford.

Chamberlain, A. 1996. "More Dating Evidence for Human Remains in British Caves." Antiquity 70: 950-953.

Chamberlain, A. 2007. "Cave Archaeology and Palaeontology in the Creswell Region." In Palaeolithic Cave Art at Creswell Crags in a European Context, edited by P. Pettitt, P. Bahn and S. Ripoll, 61-70. Oxford: Oxford University Press. 
Chamberlain, A., and J. Williams. 1998. Cave Archaeology: A Framework for Research and Assessment. Sheffield: ARCUS, University of Sheffield.

Clark, J. G. D. 1953. "Secondary Neolithic Burials at Church Dale, near Monyash, Derbyshire, 1937-39." Proceedings of the Prehistoric Society 19: 229-230.

Cockrell, T. 2016. The Don Valley in Prehistory: Upland and Lowland Developments and Interaction. Sheffield: University of Sheffield.

Collingwood, R. G., and R. P. Wright. 1991. The Roman Inscriptions of Britain II. Instrumentum Domesticum. Stroud: Alan Sutton.

Corder, P. 1951. "The Romano-British Buildings and Enclosures in Edlington Wood, near Doncaster." In Aspects of Archaeology in Britain and beyond, edited by W. F. Grimes, 66-92. London: Edwards.

Darling, M. J. 1977. A Group of Late Roman Pottery from Lincoln. Archaeology of Lincoln 16/1. London: Council for British Archaeology for Lincoln Archaeological Trust.

Davies, G., G. Robbins, D. Dungworth, A. Bogaard, and M. Parker Pearson. 1998. Archaeological Excavation of Scrooby Top Quarry Extension, Scrooby Top, Nottinghamshire. ARCUS Report 247c. Sheffield: University of Sheffield.

Didsbury, P. 2009. "Iron Age and Roman Pottery." In A Place by the Sea: Excavations at Sewerby Cottage Farm, Bridlington, edited by C. FentonThomas, 253-263. On-Site Archaeology Monograph 1. Oxford: Oxbow.

Garton, D. 1987. “Dunstan's Clump and the Brickwork Plan Field System at Babworth, Nottinghamshire. Excavations 1981." Transactions of the Thoroton Society of Nottinghamshire 49: 16-73.

Gaunt, G. D. 1994. Geology of the Country around Goole, Doncaster and the Isle of Axholme. Memoir of the British Geological Survey Sheets 79 and 88 (England and Wales). London: HMSO.

Jobey, G. 1962. "A Note on Scooped Enclosures in Northumberland." Archaeologia Aeliana 4th Series 40: 47-58.

Jones, L. 2007. "Archaeological Excavation of a Brickwork Plan Field System at Catesby Business

Park, Balby Carr, Doncaster, South Yorkshire, 2002." Yorkshire Archaeological Journal 79: 37-49. Leach, S. 2006. Going Underground: An Anthropological and Taphonomic Study of Human Skeletal Remains from Caves and Rock Shelters in Yorkshire. Leeds: Yorkshire Archaeological Society. 
Mackreth, D. F. 2011. Brooches in Late Iron Age and Roman Britain. Oxford: Oxbow.

Magilton, J. 1977. The Doncaster District: An Archaeological Survey. Doncaster: Museum and Art Gallery.

Mainman, A. J., and N. S. H. Rogers. 2000. The Archaeology of York. the Small Finds 17/4. Craft, Industry and Everyday Life. York: Council for British Archaeology for York Archaeological Trust.

May, J. 1996. Dragonby. Report on Excavations at an Iron Age and Romano-British Settlement in North Lincolnshire. Oxford: Oxbow.

Mercer, R. J. 1999. "The Origins of Warfare in the British Isles.” In Ancient Warfare: Archaeological Perspectives, edited by J. Carman, J. and A. Harding, 143156. Stroud: Sutton.

O'Connor, T. 2001. "Appendix 1. Rossington Bridge: Coins and Copper-Alloy Objects Reported to Doncaster Museum and Art Galler y". In The Roman Pottery Industry at Rossington Bridge: Excavations 1956-61, edited by P. Buckland, K. F. Hartley, and V. Rigby, 91. Journal of Roman Pottery Studies 9: 1-96.

Pearson, M. P., and R. E. Sydes. 1997. "The Iron Age Enclosures and Prehistoric Landscape of Sutton Common, South Yorkshire." Proceedings of the Prehistoric Society 63: 221-259.

Perrin, J. R. 1999. "Roman Pottery from Excavations at and near to the Roman Small Town of

Durobrivae, Water Newton, Cambridgeshire, 1956-58." Journal of Roman Pottery Studies 8: 1-141. Piggott, S. 1954. The Neolithic Cultures of the British Isles. Cambridge: Cambridge University Press.

Ramm, H. G. 1973. “The Antiquities in Edlington Wood.” In Edlington Wood: An Assessment of Its Recent History, Archaeology, Geology, Natural History and Educational and Amenity Value, edited by H. Phillips, 27-34. Doncaster: Doncaster Rural District Council.

Rega, E. A. 1992. "Osteological Analysis." In When Rolling Stones Are Taphonomous. A Rock Shelter Burial at Scabba Wood, Sprotborough, South Yorkshire, edited by A. Chadwick. Unpublished report, Sheffield: South Yorkshire Archaeology Service.

Richardson, J. 2008. The Late Iron Age and Romano-British Rural Landscape of Gunhills, Armthorpe, South Yorkshire. Wakefield: WYAS Archaeological Services. 
Rigby, V. 2004. "Pots in Pits: The British Museum Yorkshire Settlements Project 1988-92." East Riding Archaeologist 11: 1-228.

Riley, D. N. 1980. Early Landscape from the Air. Sheffield: University of Sheffield.

Roberts, I. 2010. Understanding the Cropmark Landscapes of the Magnesian Limestone. Wakefield: Archaeological Services WYAS \& English Heritage.

Sainty, D. 2007. Discover Ancient Don Gorge. The Story of Don Gorge from Prehistoric to Anglo-Saxon times. Sheffield: InHeritage for Doncaster Metropolitan Borough Council. http://www.yourfind. org.uk/DiscoverAncientDonGorgereport.pdf.

Smith, B. M. 2002. A Palaeoecological Study of Raised Mires in the Humberhead Levels. British Archaeological Reports British Series 336. Oxford.

Stead, I. M. 1971. "Yorkshire before the Romans: Some Recent Discoveries." In Soldier and Civilian in Roman Yorkshire, edited by R. M. Butler, 21-44. Leicester: Leicester University Press.

Steers, A. D. 1995. The Geophysical Survey at Sprotborough, Doncaster, 1994. Doncaster: Doncaster Group of the Yorkshire Archaeological Society. Unpublished report.

Sutton, J. E. G. 1986. "The Sirikwa Holes and Their Houses on Hyrax Hill." Nyame Akuma 27: 18-23.

Van de Noort, R., H. Chapman, and J. R. Collis, eds. 2007. Sutton Common: The Excavation of an Iron Age 'Marsh Fort'. Council for British Archaeology research report 154 . York.

Webster, G., and N. Booth. 1947. "A Romano-British Pottery Kiln at Swanpool, near Lincoln.” The Antiquaries Journal 27: 61-79.

White, G. F. 1966. Scratta Wood. Iron Age Excavations 1959-1965. Worksop: Worksop Corporation.

Whiting, C. E. 1936. "Excavations on Sutton Common, 1933, 1934 and 1935." Yorkshire Archaeological Journal 33: 57-80. 


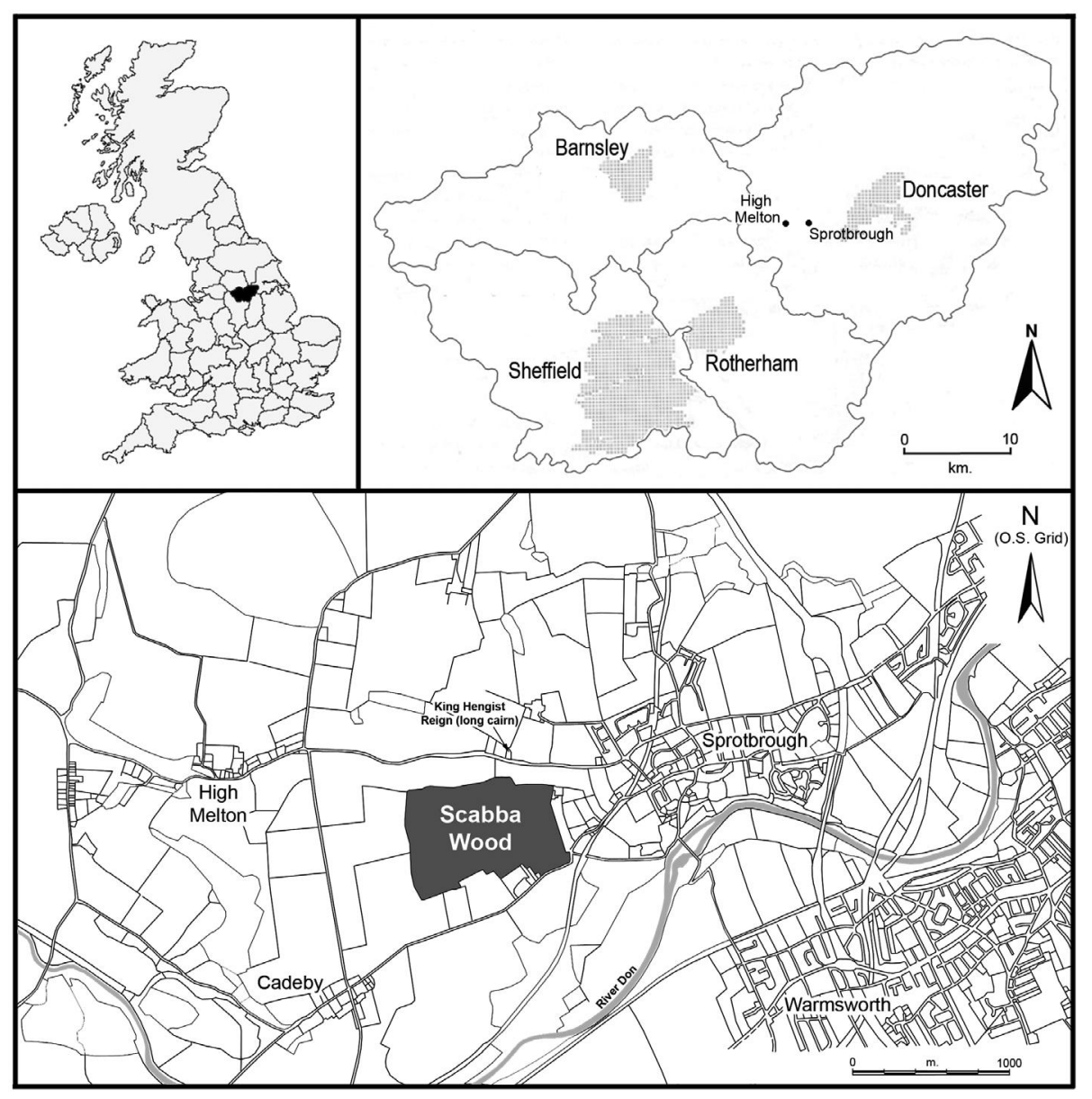

Figure 1. The location of Scabba Wood, Sprotbrough. Map data derived from O.S. mapping () Crown Copyright and Database Right 2016. Ordnance Survey (Digimap licence). 


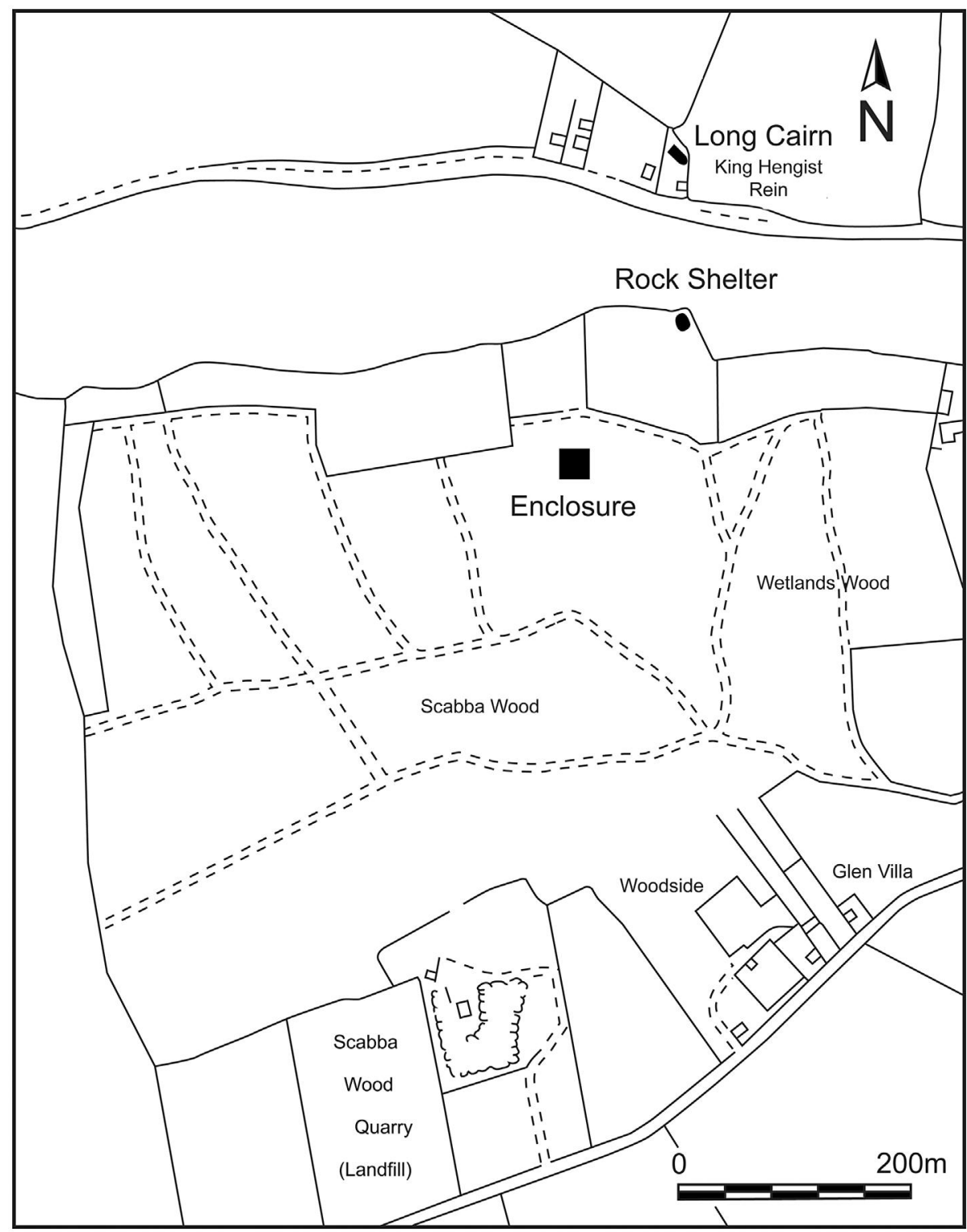

Figure 2. The locations of the enclosure and rock shelter within Scabba Wood, Sprotbrough. 


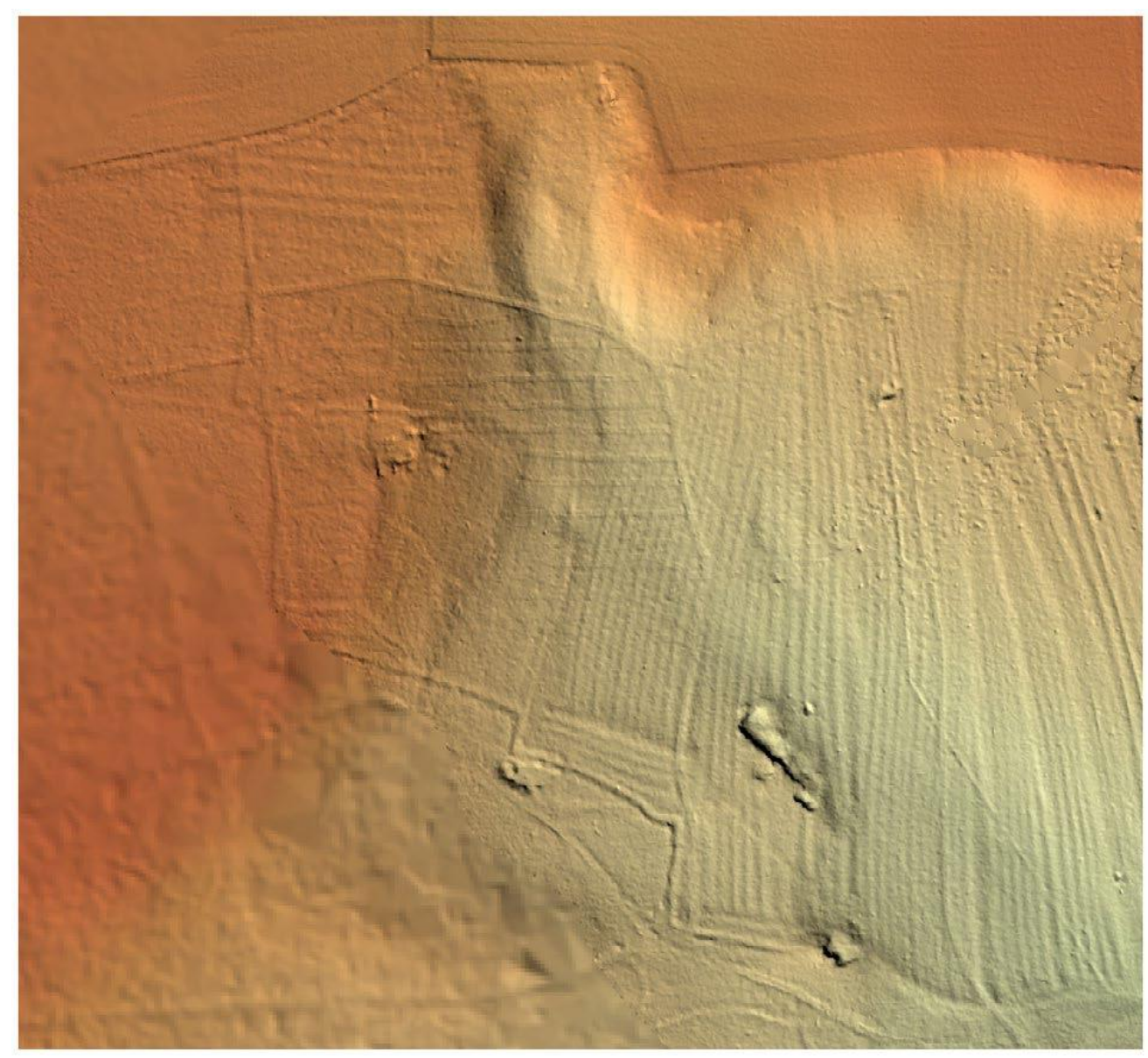

Figure 3. LiDAr image of part of Scabba Wood, centred on SE527017. The partly excavated enclosure is evident centre left, within a system of broad east-west rigs bounded by a low bank. These are in part overlain by north-south narrow rig and furrow which is disturbed lower right of centre by later quarrying. small subrectangular fields appear to surround the enclosure but their relationship with the broad rigs is obscure. The rock outcrop associated with the burials is visible centre top, close to the field boundary. Image processed by T. Prosser from Environment Agency $($ ) data. 


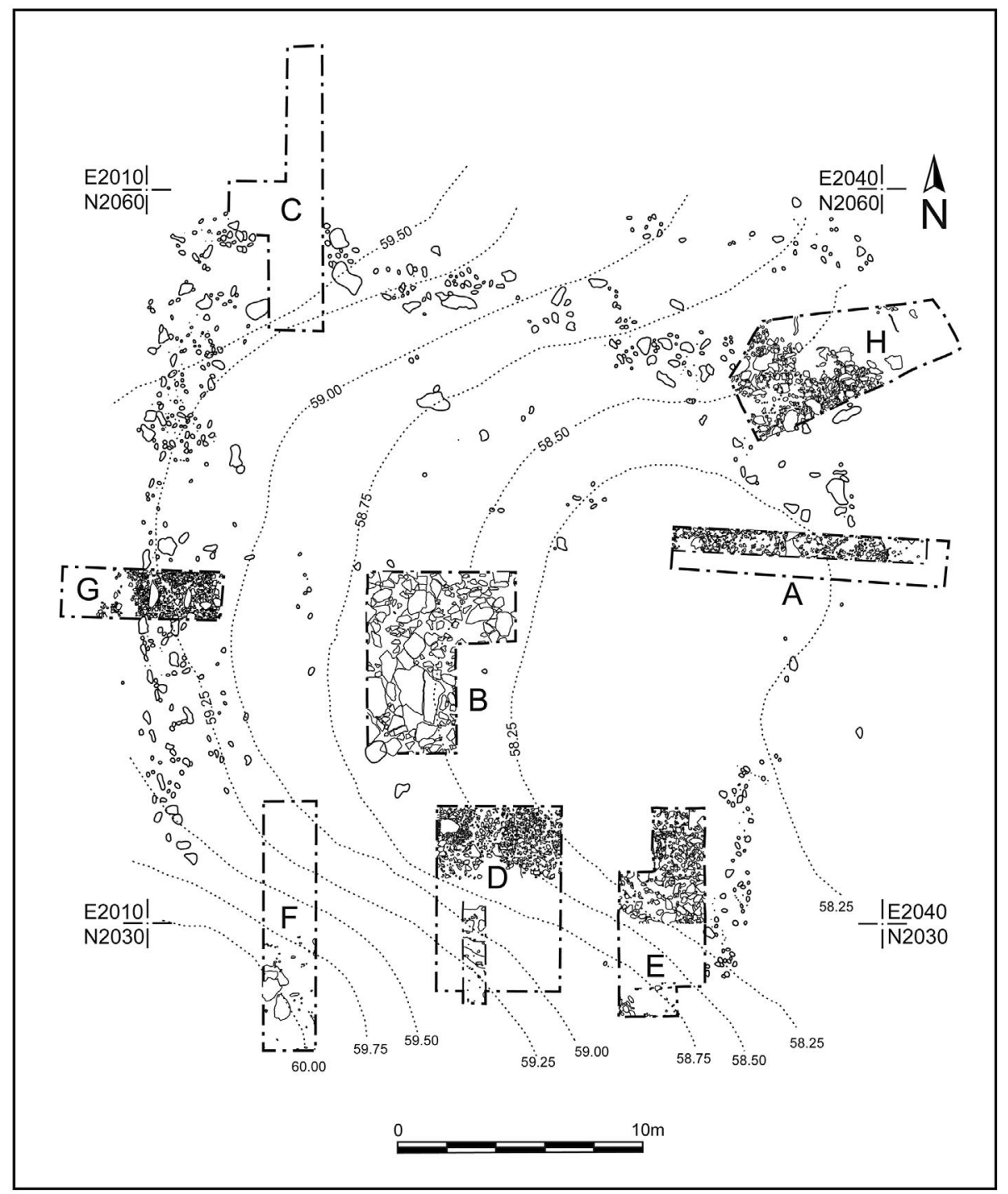

Figure 4. Plan of the Scabba Wood enclosure, showing the positions of Trenches A$\mathrm{H}$. 


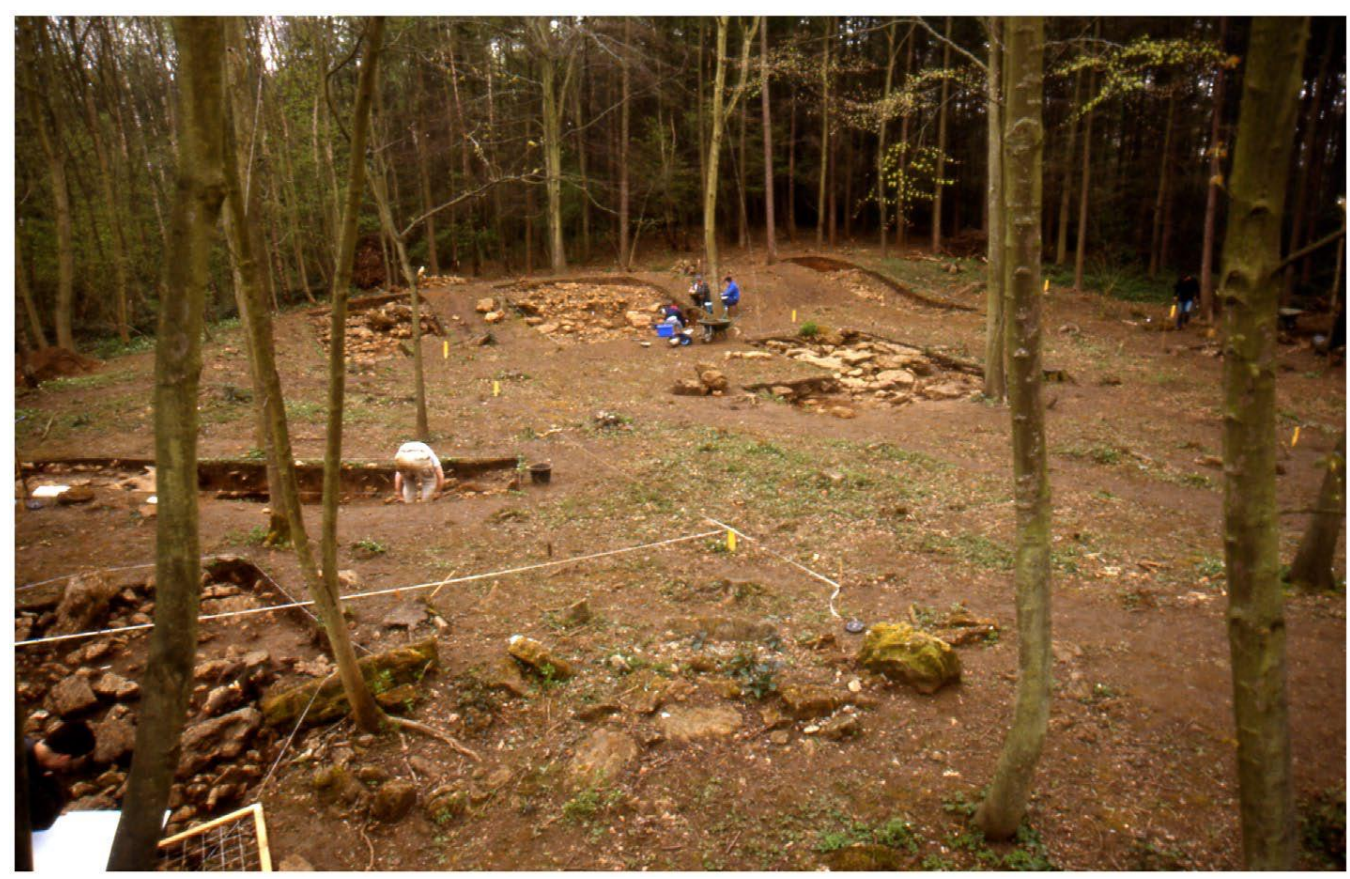

Figure 5. Scabba Wood: the enclosure viewed from the north-east during excavations in 1998.

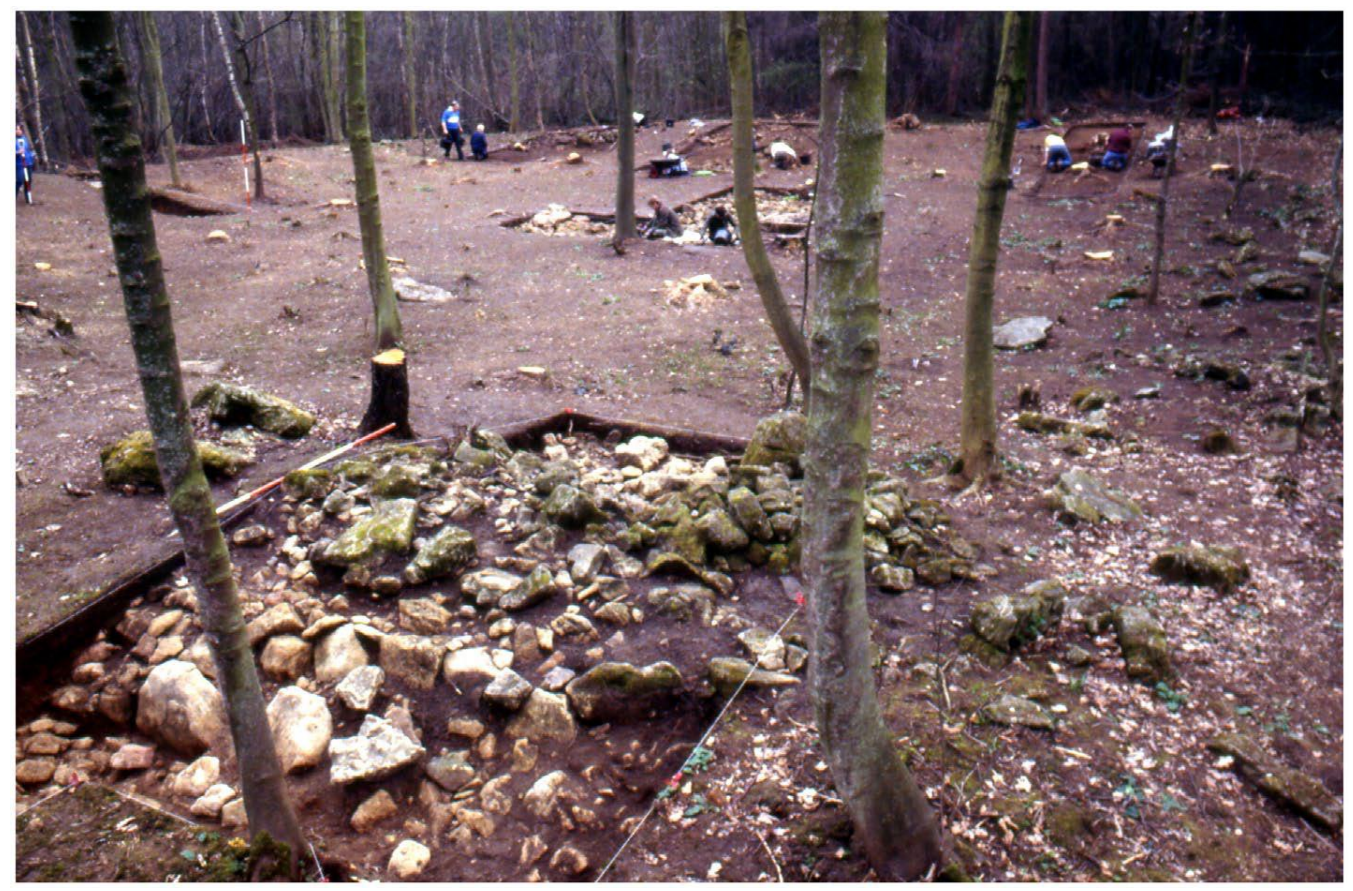

Figure 6. Scabba Wood: the enclosure viewed from the north-west during excavations in 1997. 


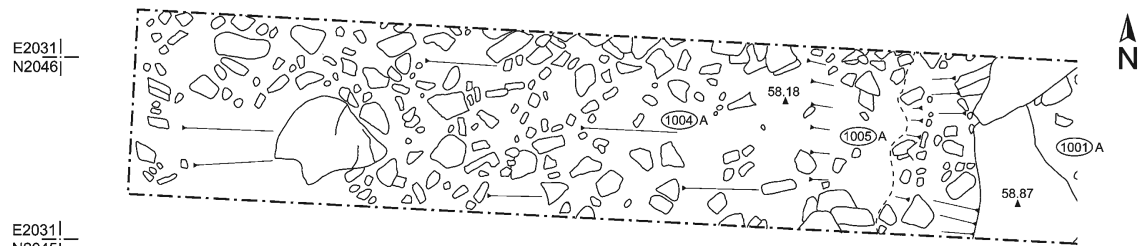

$\left.{ }_{\mathrm{N} 20345}^{\mathrm{E} 2031}\right|^{-}$

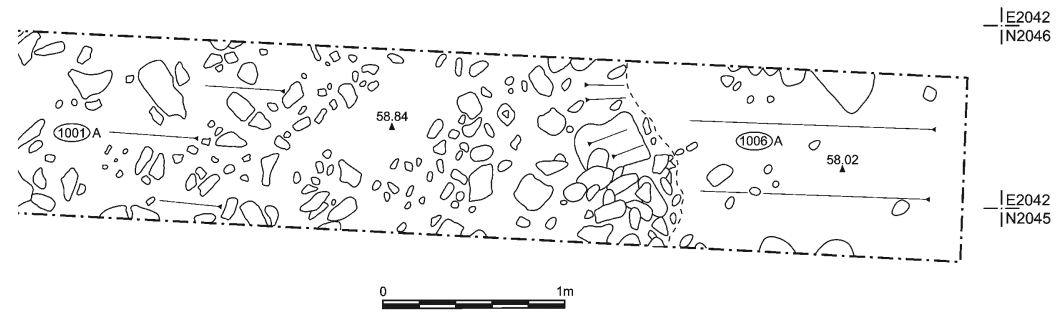

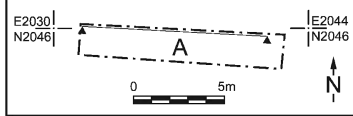

w

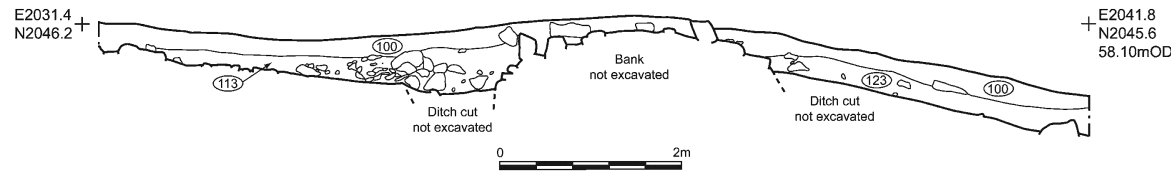

Figure 7. Scabba Wood: plan and section of Trench A. 


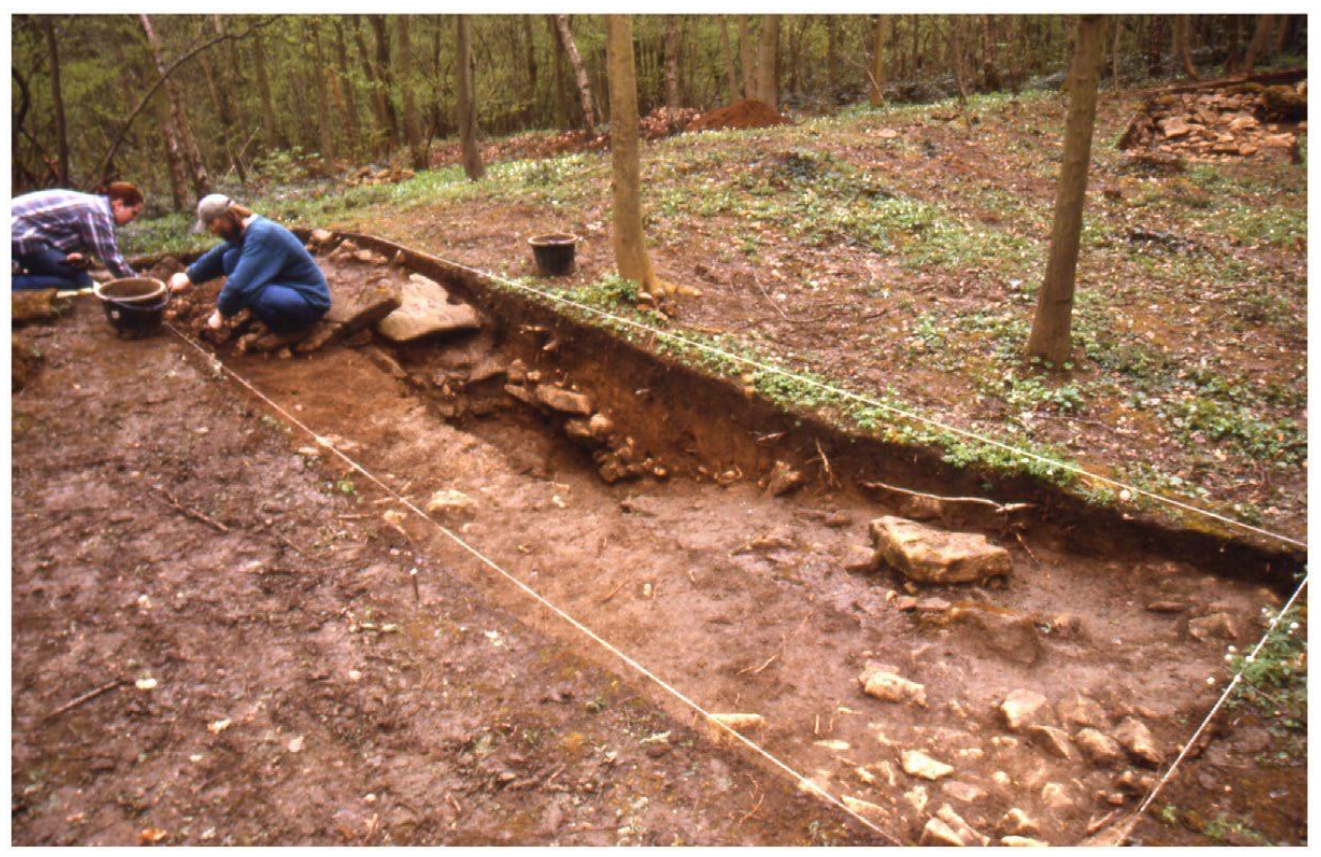

Figure 8. Scabba Wood: Trench A during excavation looking S.

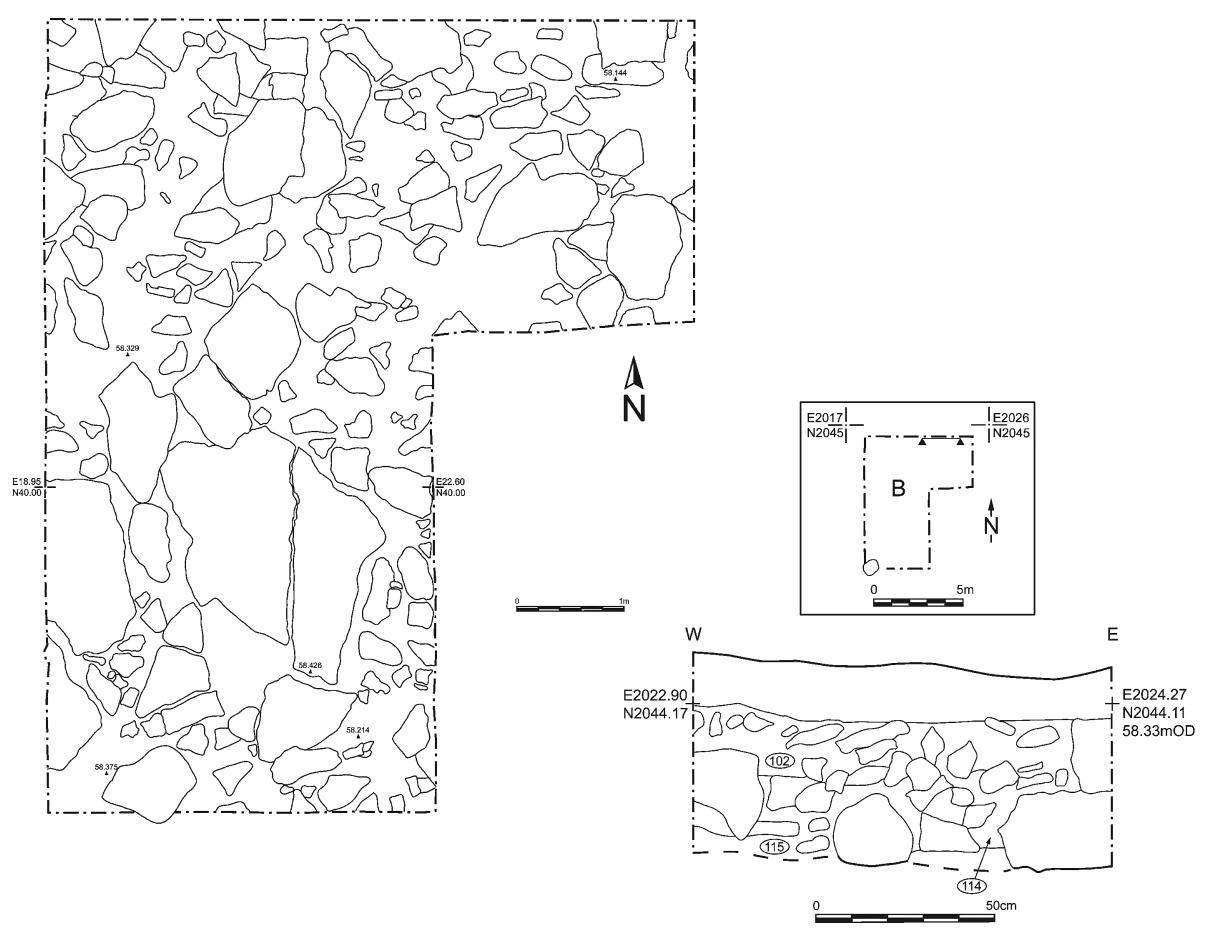

Figure 9. Scabba Wood: plan and section of Trench B. 


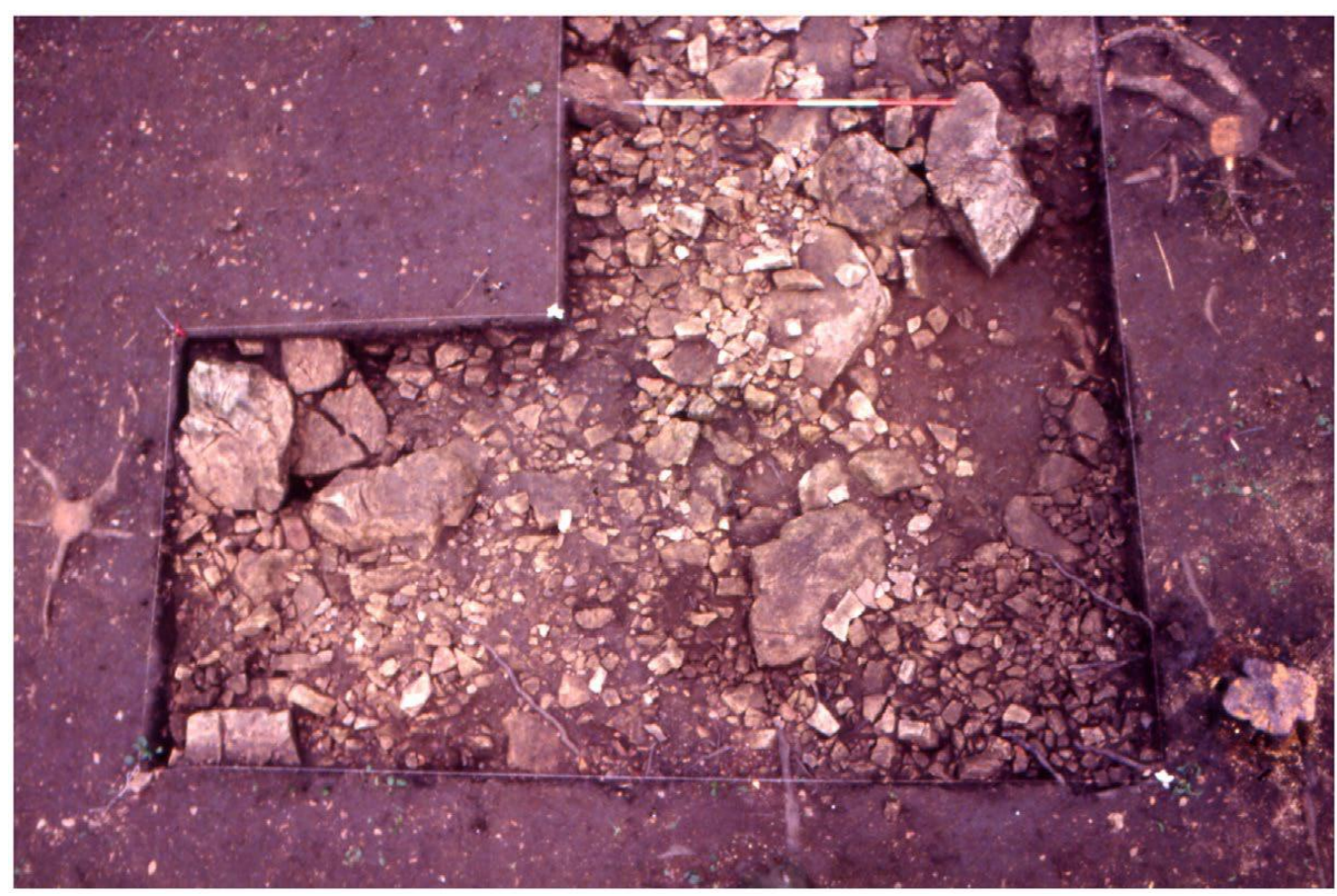

Figure 10. Scabba Wood: Trench B viewed from the north in 1997.
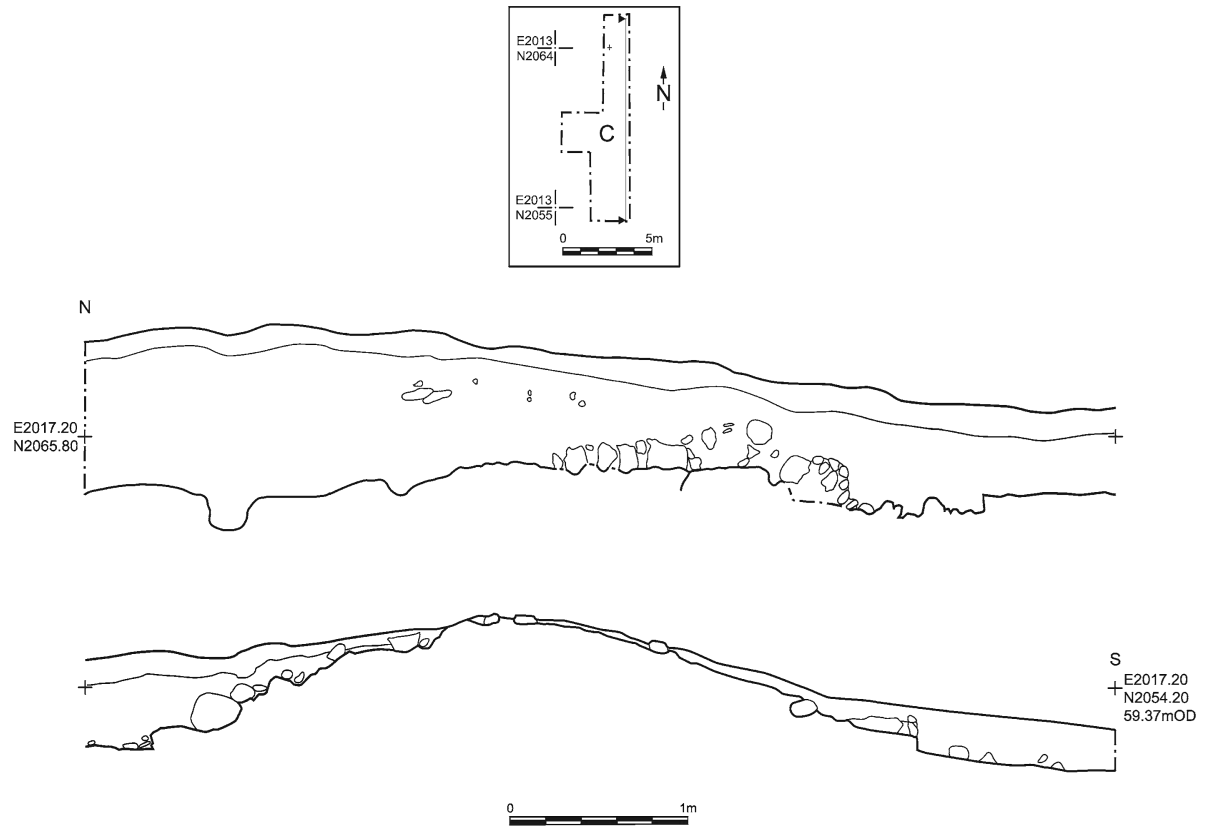

Figure 11. Scabba Wood: Trench C section. 


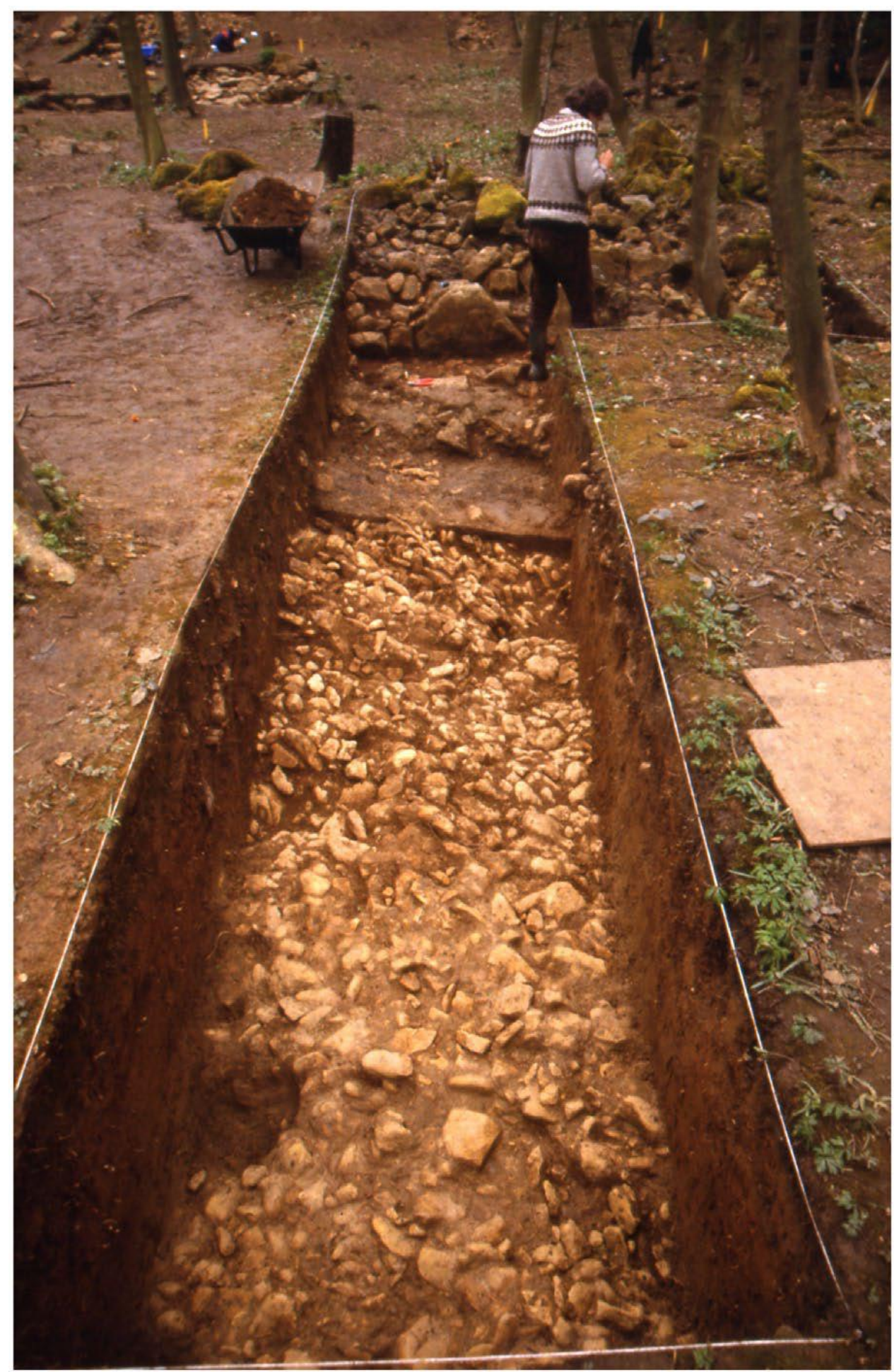

Figure 12. Scabba Wood: Trench C viewed from the north in 1998; one of the orthostats of the enclosure wall is visible to the left of the figure. 


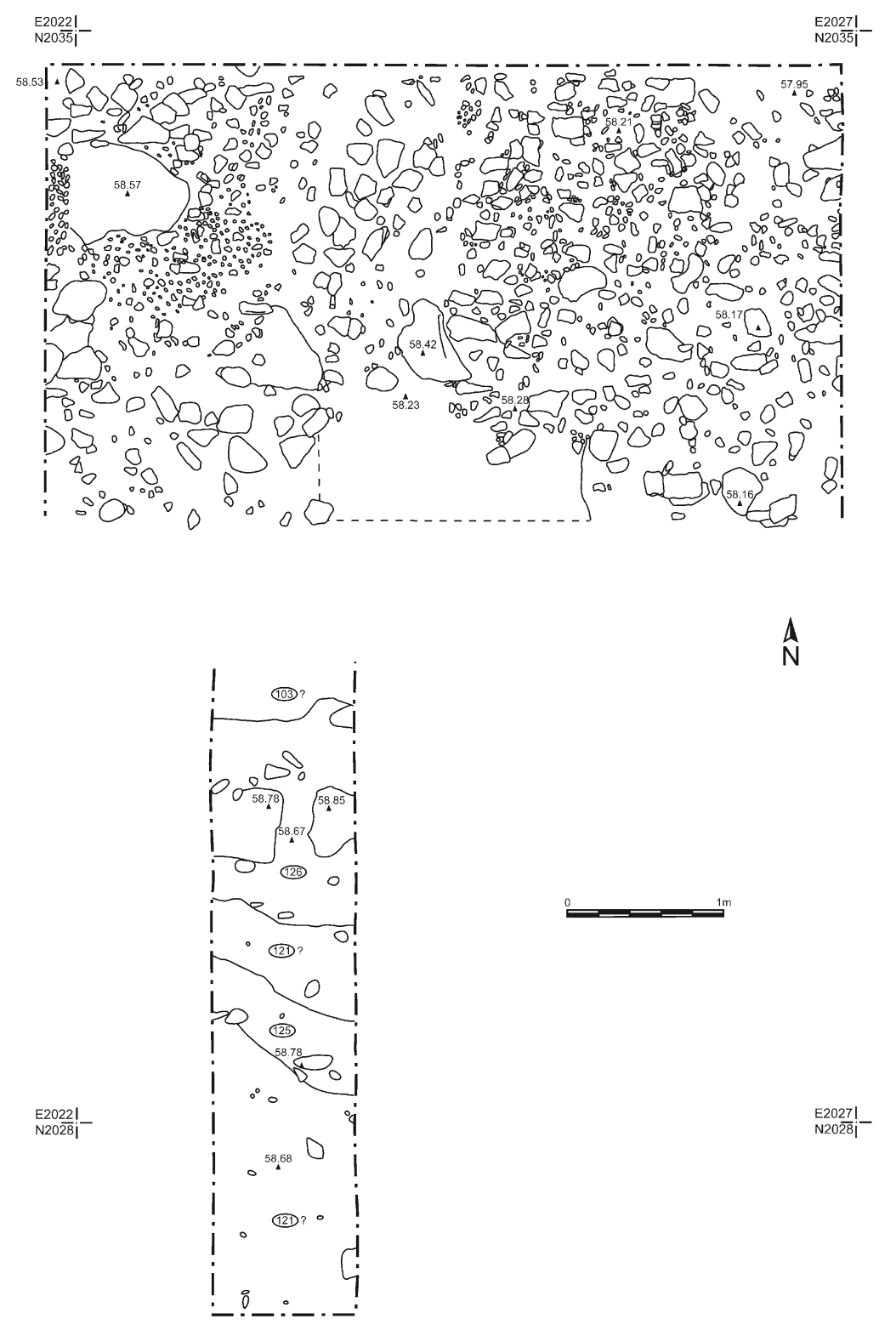

Figure 13. Scabba Wood: plan of Trench D. 

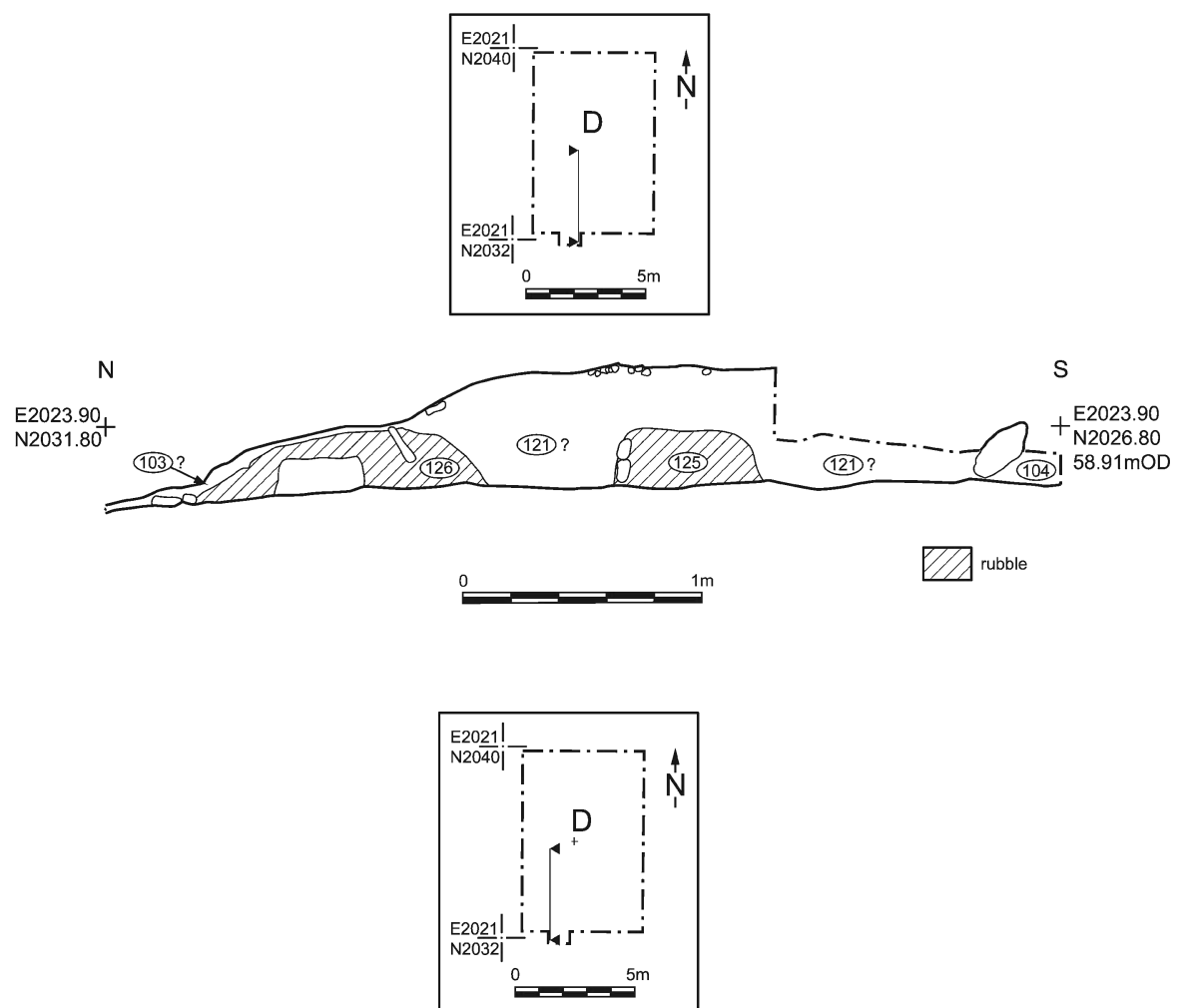

$S$

N

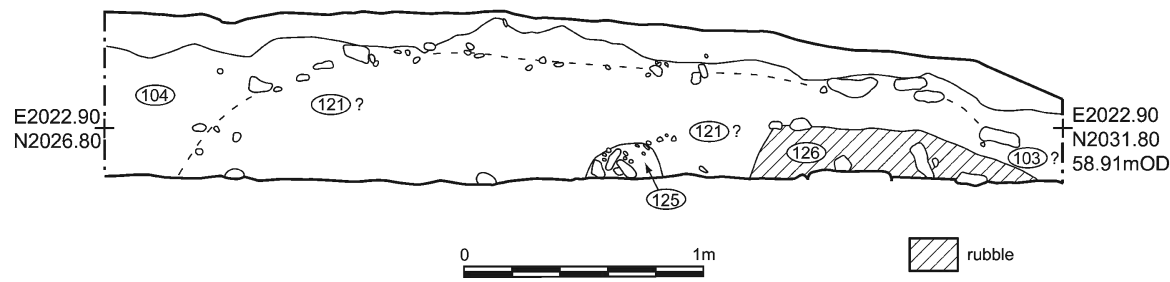

Figure 14. Scabba Wood: sections within Trench D. 


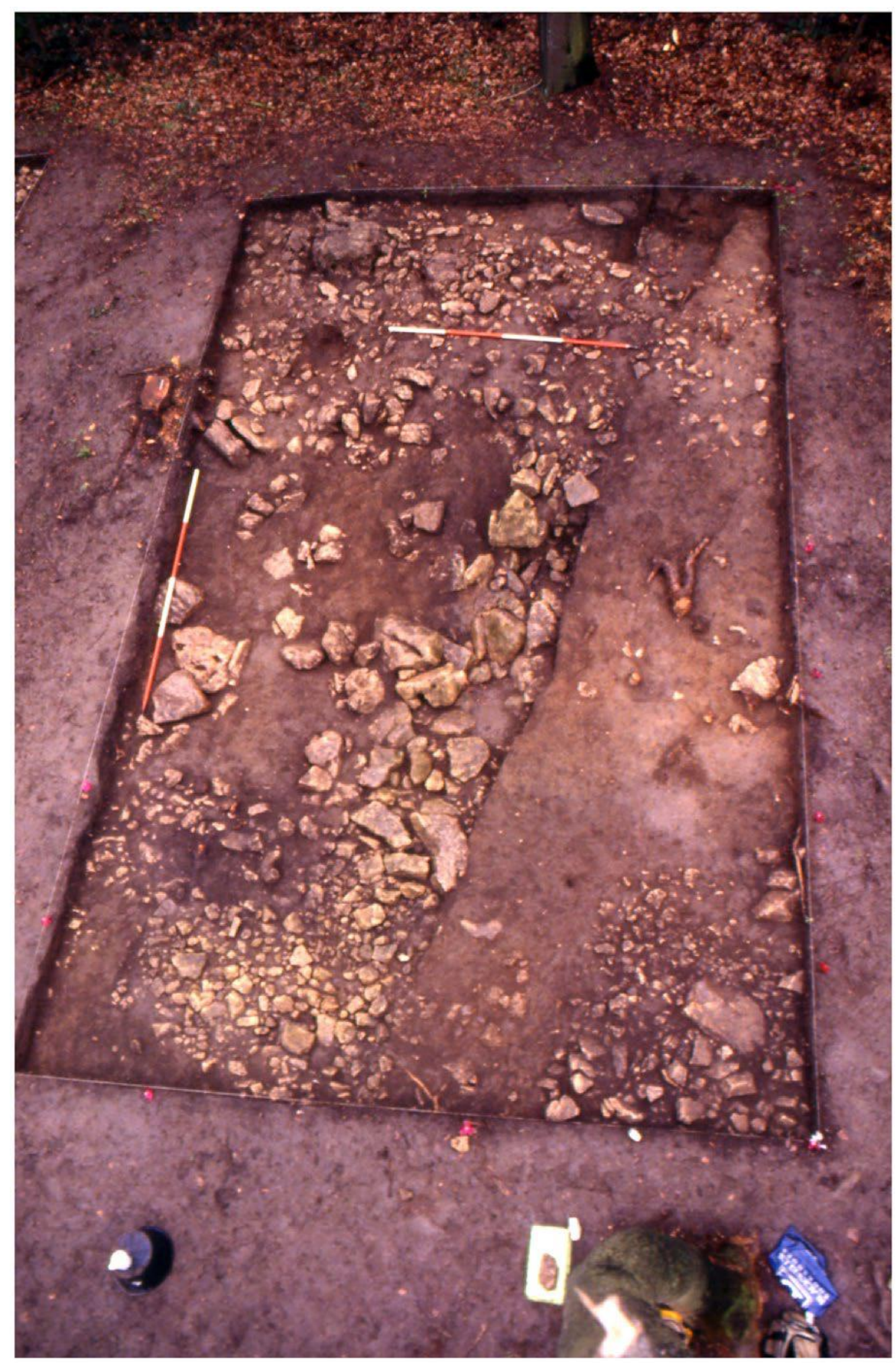

Figure 15. Scabba Wood: Trench D viewed from the north in 1997. 


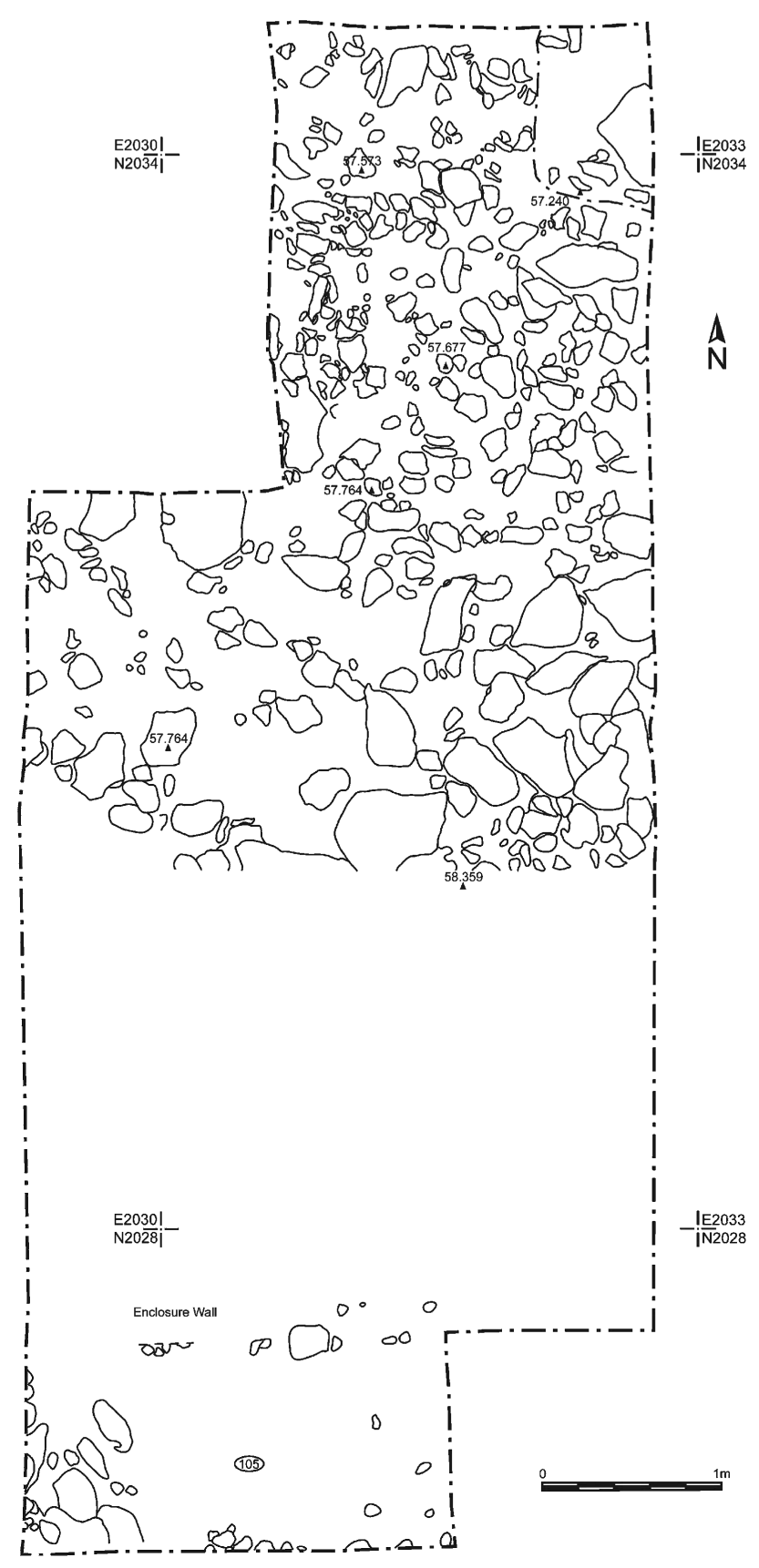

Figure 16. Scabba Wood: plan of Trench E. 

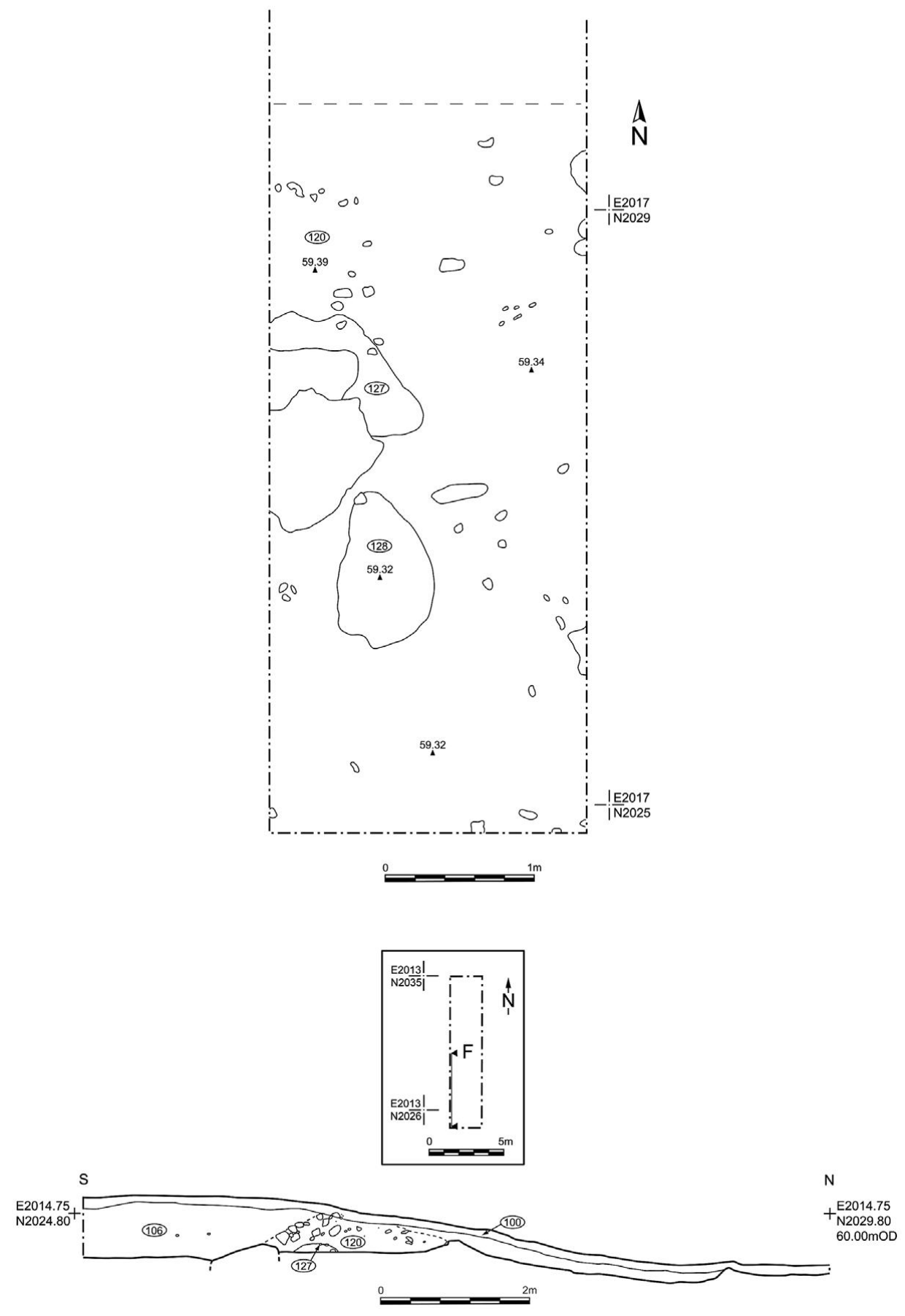

Figure 17. Scabba Wood: plan and section of Trench F. 
$\stackrel{A}{N}$

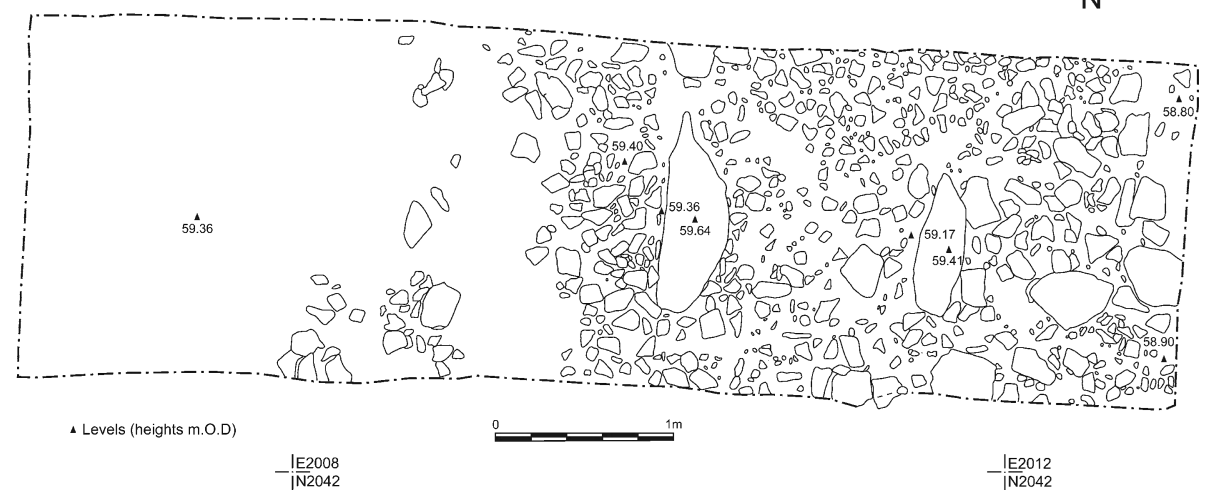

Figure 18. Scabba Wood: plan of Trench G.

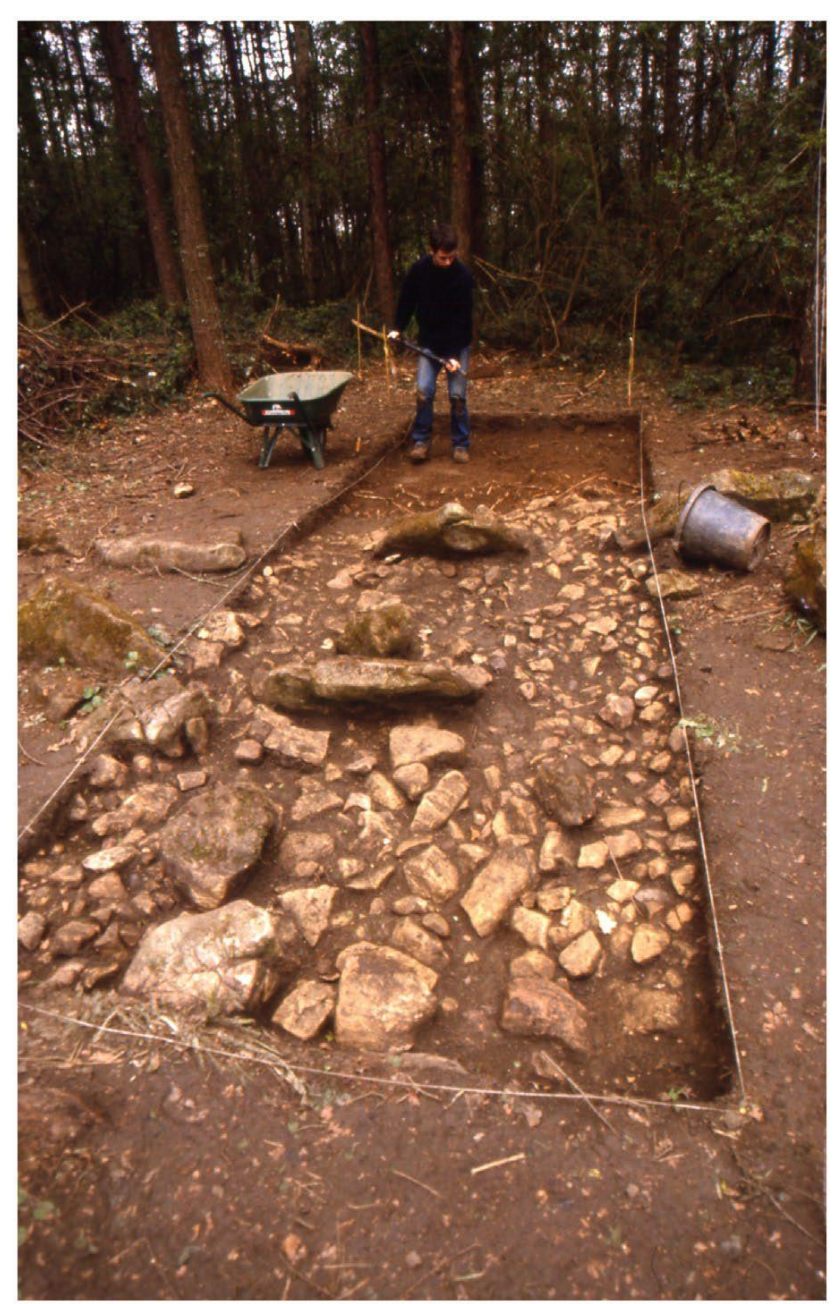

Figure 19. Scabba Wood: Trench G viewed from the east in 1998; the two orthostats either side of the wall core are visible in the centre of the trench. 


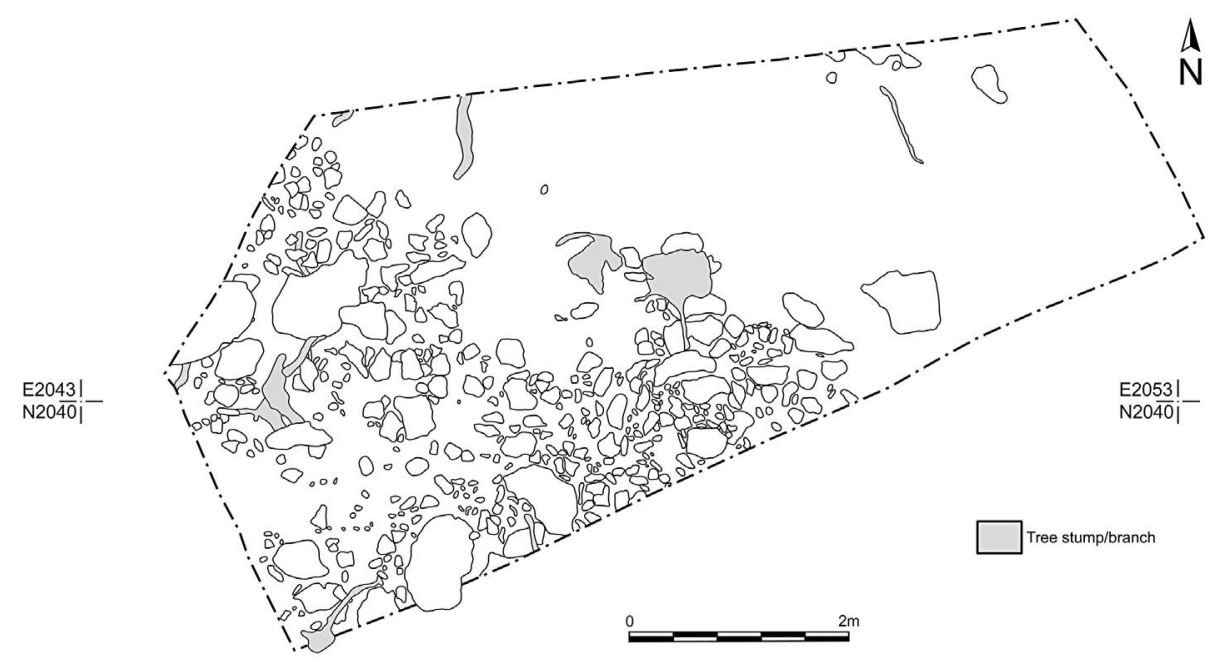

Figure 20. Scabba Wood: plan of Trench H.

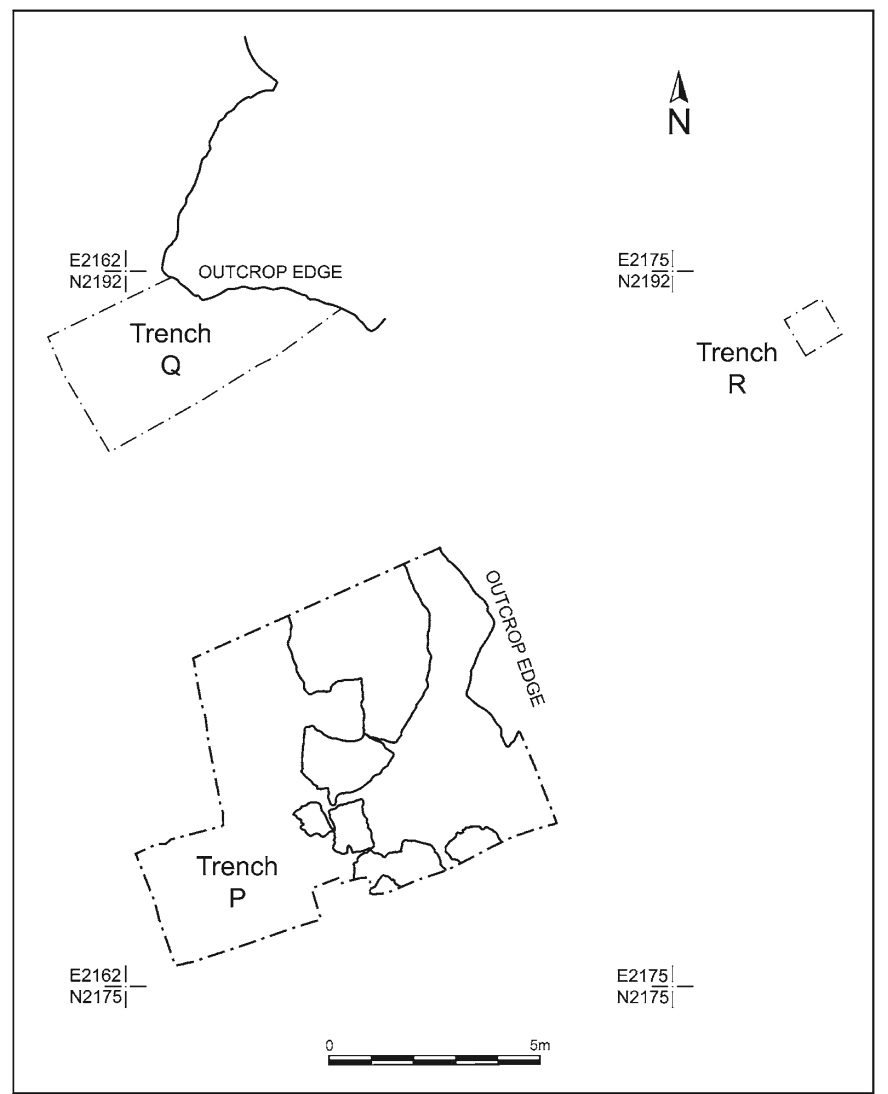

Figure 21. Scabba Wood: plan of the rock shelter Trenches P, Q and R. 


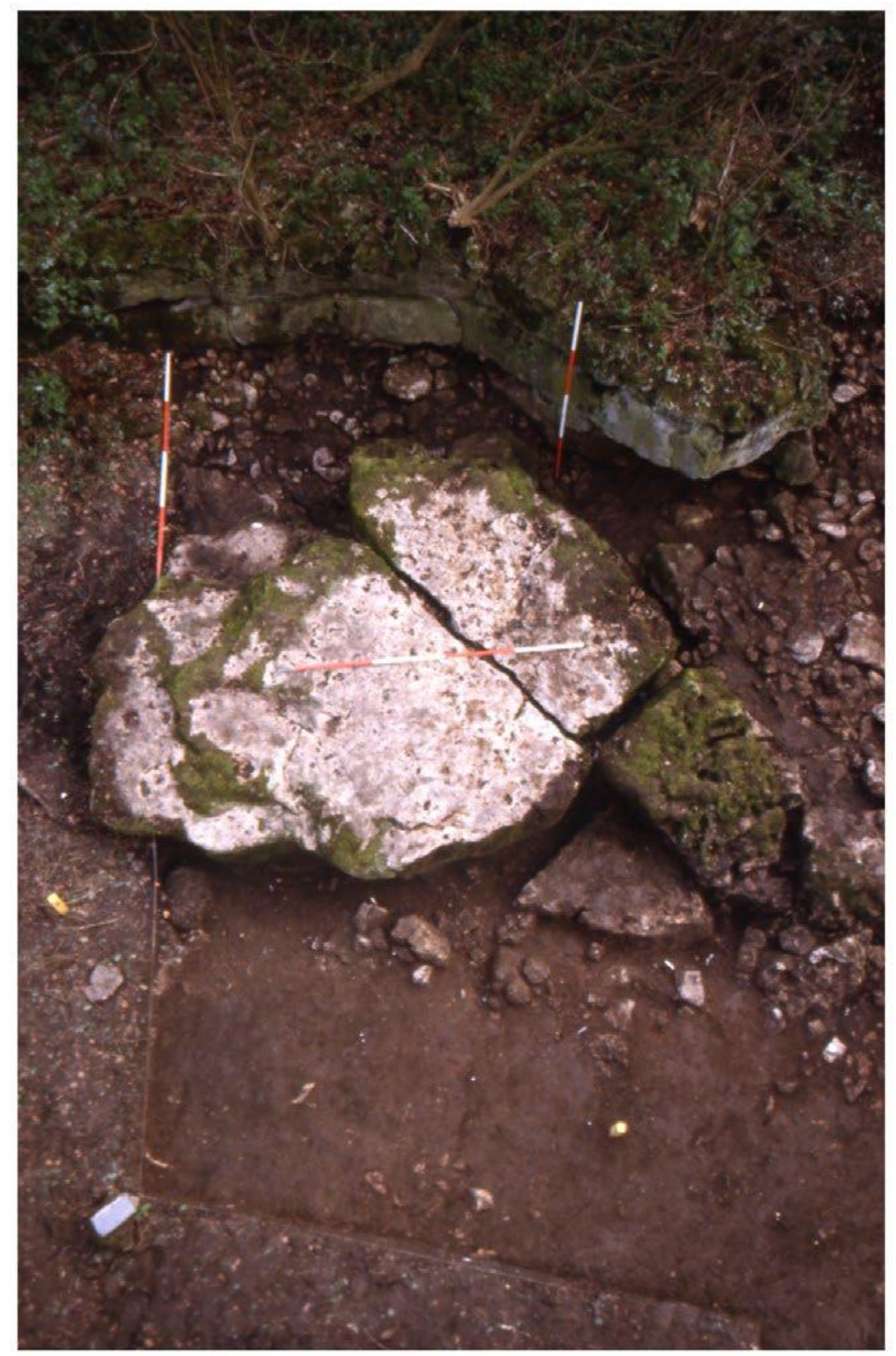

Figure 22. Scabba Wood: aerial view of Trench P from the south-west, showing the large boulder within the trench. 


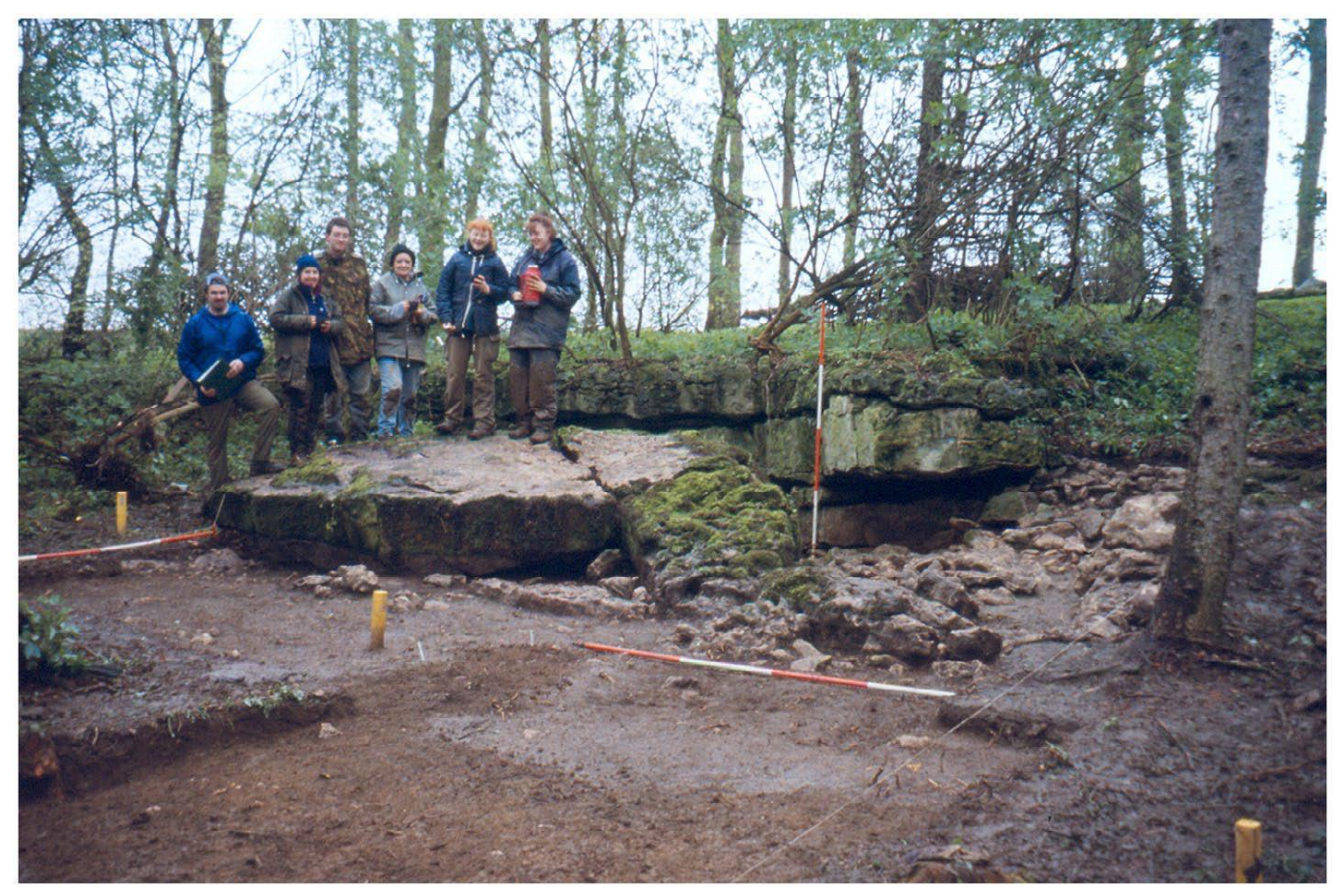

Figure 23. Scabba Wood: Trench P viewed from the south, showing the façade of the outcrop. 


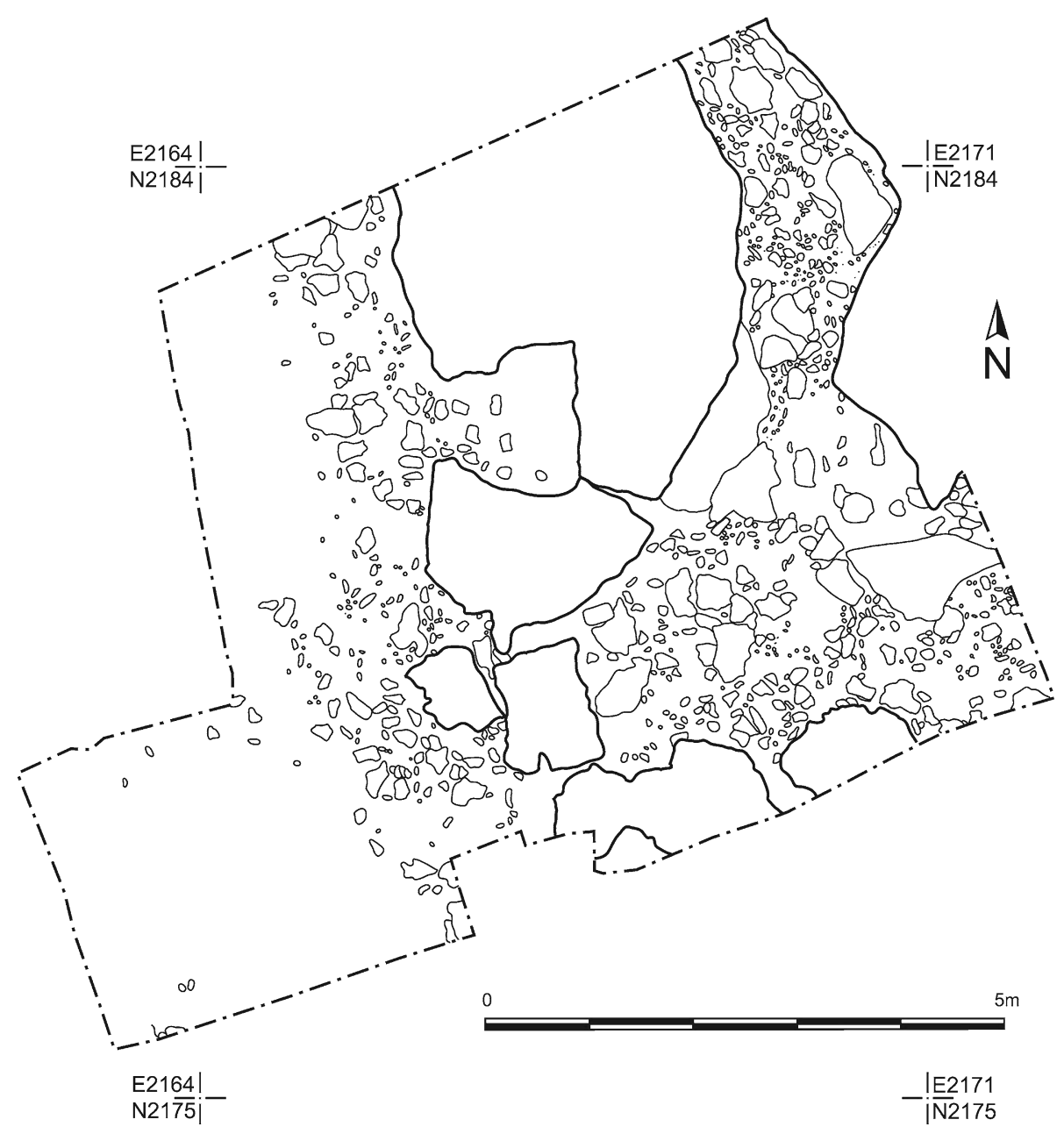

Figure 24. Scabba Wood: plan of Trench P. 


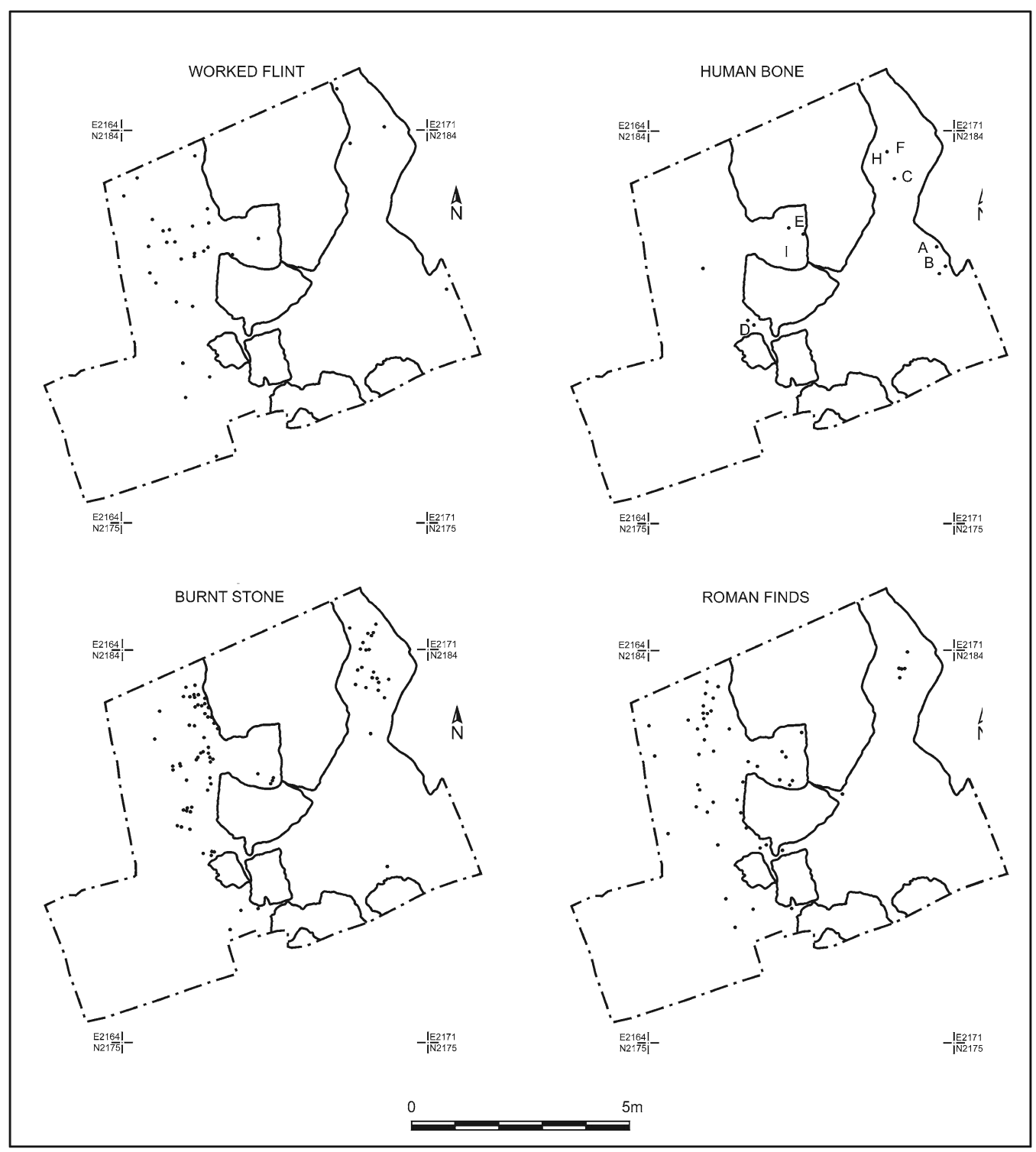

Figure 25. Scabba Wood: spatial distribution of selected artefact types within all layers in Trench P: worked flint, human bone, burnt stone and Roman finds. 


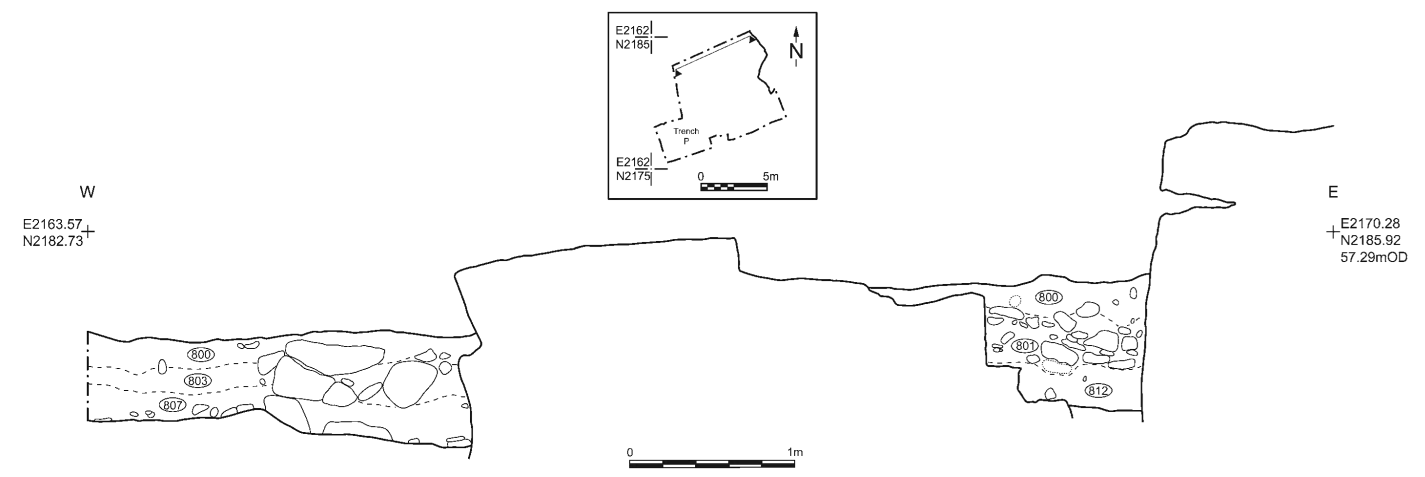

Figure 26. Scabba Wood: the north section of Trench P.
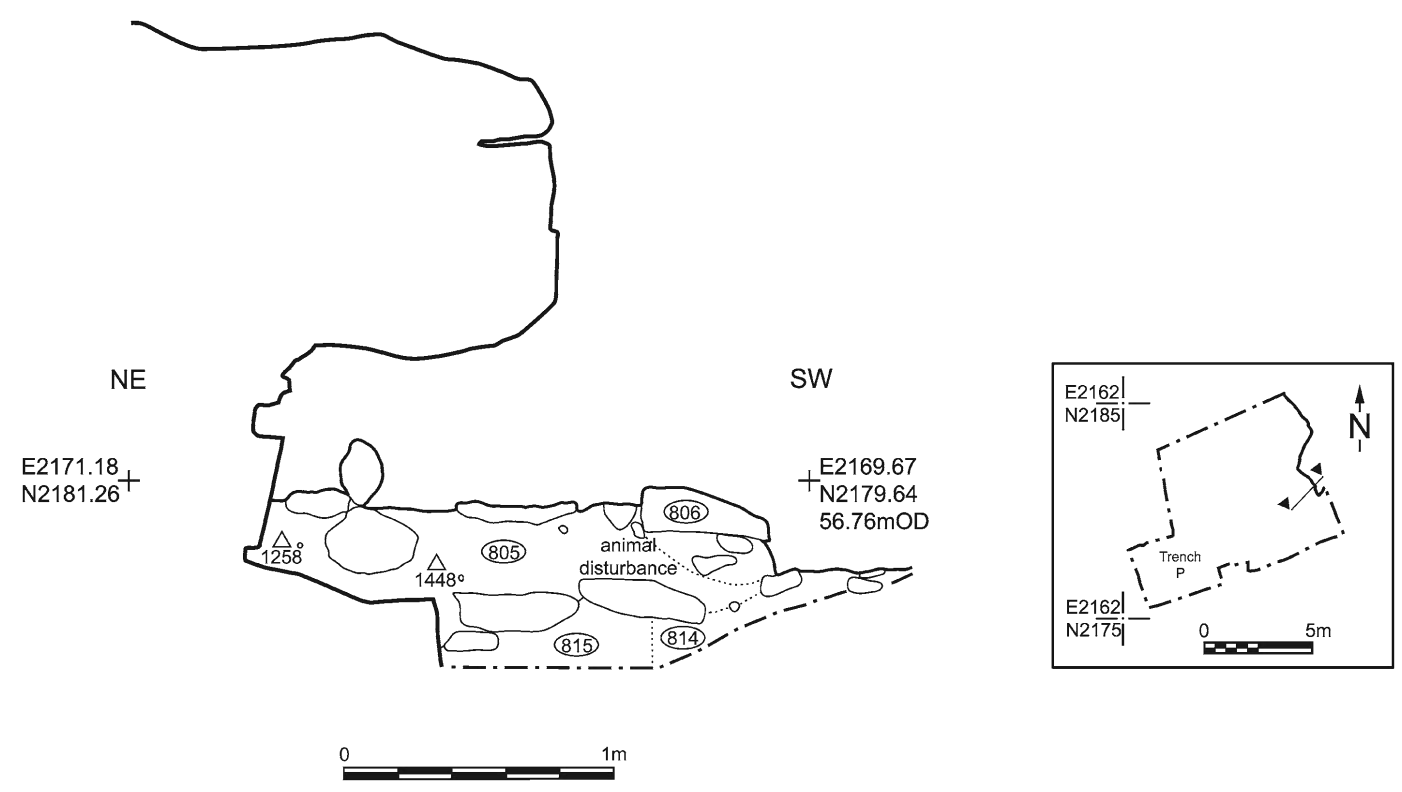

Figure 27. Scabba Wood: section drawn in 1998 in Trench P through the overhang where Middle Neolithic human remains were found in 1992. 


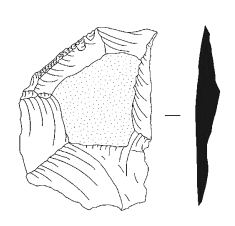

Trench D

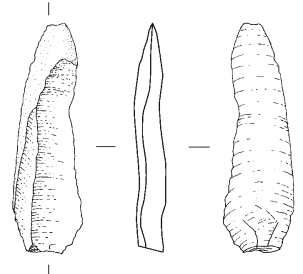

1400

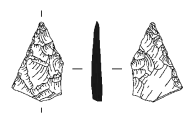

1505

808

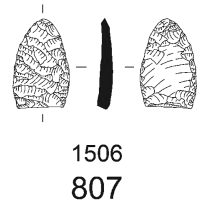

807

Figure 28. Lithics from the Scabba Wood enclosure (Trench D) and rock shelter (1400, 1505 and 1506).

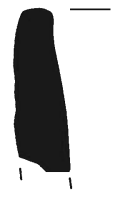

1429

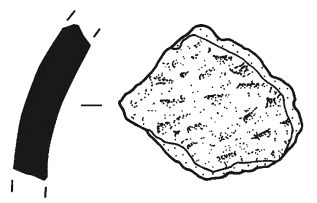

1500

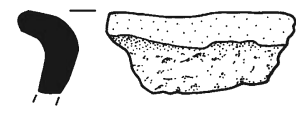

1461

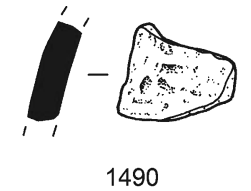

1490

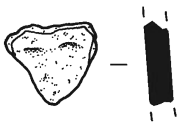

1512

807

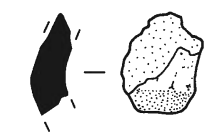

1568

807

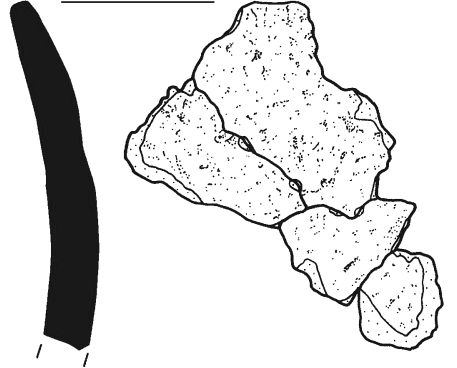

1530

812

Figure 29. Prehistoric ceramics from layers 807 and 812 at Scabba Wood rock shelter. 

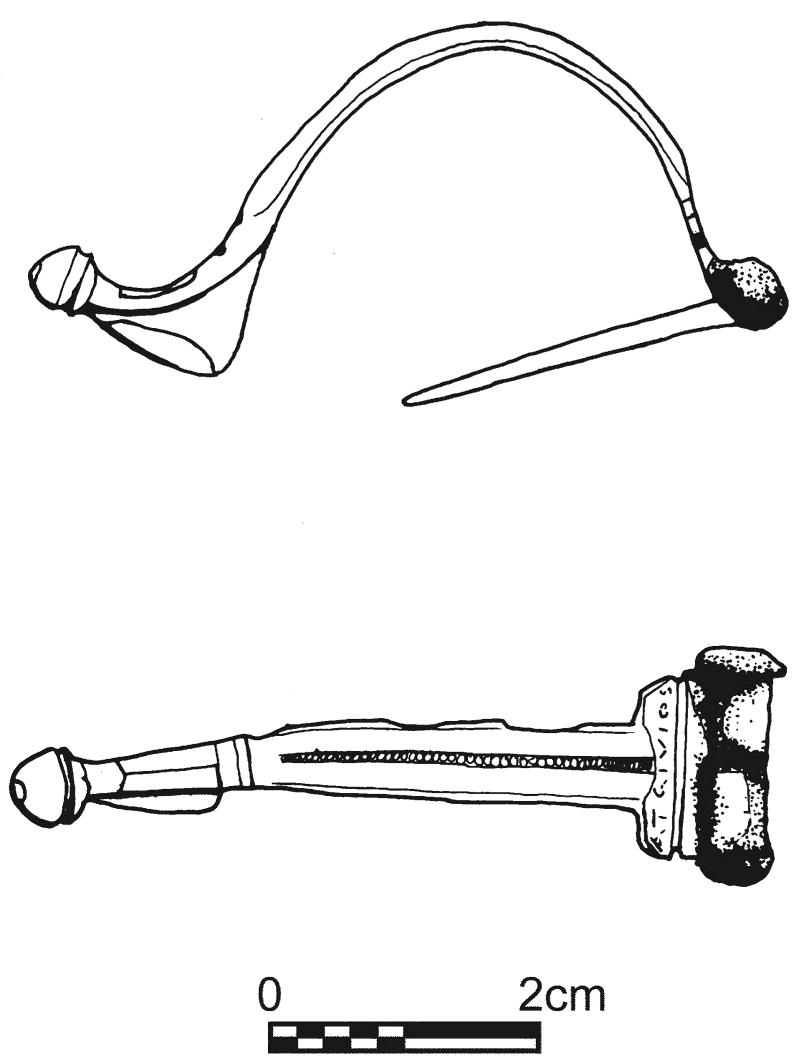

Figure 30. Scabba Wood: AVCISSA-type brooch with the stamp ATGIVIOS.
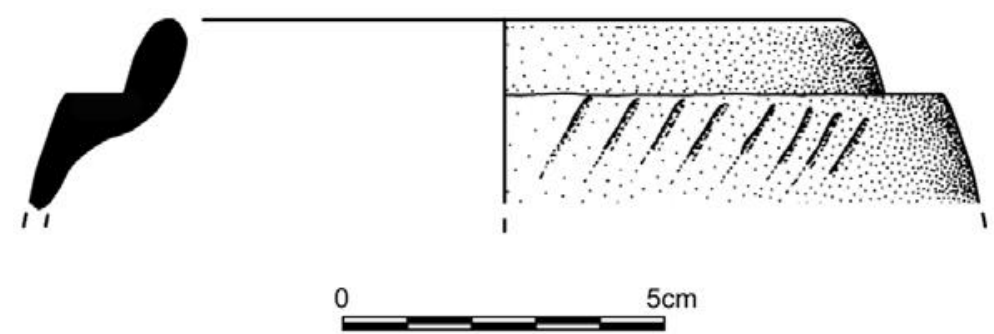

Figure 31. Scabba Wood: Roman colour-coated beaker sherd from Trench D. 


\begin{tabular}{|c|c|c|c|c|}
\hline Specimen & Context & Anatomical part & Individual & Age \\
\hline 1216 & 800 & $\begin{array}{l}\text { Left mandibular deciduous second molar, } \\
\text { heavily worn with partially resorbed } \\
\text { roots }\end{array}$ & Individual B & c. 12 years \\
\hline 1220 & 800 & $\begin{array}{l}\text { Right mandibular permanent second or } \\
\text { third molar, with } 1 / 4 \text { root development }\end{array}$ & $\begin{array}{l}\text { Individual B (poss. } \\
\text { Individual D) }\end{array}$ & c. 14 years (poss. 8-9 years) \\
\hline 1258 & 802 & Proximal hand phalanx & - & - \\
\hline 1409 & 805 & Middle hand phalanx & - & - \\
\hline 1448 & 805 & Right 2nd metacarpal fragment & Individual B or C & - \\
\hline 1494 & 805 & Scapula?/acromial process & - & - \\
\hline 1573 & 807 & $\begin{array}{l}\text { Left mandibular permanent first molar, } \\
\text { slightly worn. Mesial wear facet may } \\
\text { match } 800-1216 \text {. }\end{array}$ & Individual B & c. 12 years \\
\hline \# & 807 & Maxillary premolar, heavily worn & Individual C & Older adult \\
\hline 1519 & 808 & $\begin{array}{l}\text { Right maxillary central permanent incisor, } \\
\text { slight wear with ribbon dentine exposure }\end{array}$ & Individual B & $12-15$ years \\
\hline 1446 & 808 & $\begin{array}{l}\text { Left mandibular permanent canine, slight } \\
\text { wear with small exposure of dentine }\end{array}$ & Individual B & $12-15$ years \\
\hline 1536 & 812 & Middle hand phalanx & - & - \\
\hline 1543 & 812 & Left zygomatic (frontal process) & - & - \\
\hline 1561 & 812 & $\begin{array}{l}\text { Left mandible fragment (gonial angle), } \\
\text { matches } 812 / 1579\end{array}$ & $\begin{array}{l}\text { Possible Individual } \\
\text { C }\end{array}$ & - \\
\hline 1579 & 812 & $\begin{array}{l}\text { Left mandible fragment (corpus, with } \\
\text { tooth socket), matches } 812 / 1561\end{array}$ & $\begin{array}{l}\text { Possible Individual } \\
\text { C }\end{array}$ & - \\
\hline 1580 & 812 & $\begin{array}{l}\text { Left mandibular permanent first molar, } \\
\text { heavily worn }\end{array}$ & Individual C & $30-40$ years \\
\hline 1581 & 812 & Proximal hand phalanx & - & - \\
\hline 1582 & 812 & $\begin{array}{l}\text { Right mandible fragment (gonial angle) } \\
\text { probable match to } 812 / 1561 \& 812 / 1579\end{array}$ & $\begin{array}{l}\text { Possible Individual } \\
\text { C }\end{array}$ & - \\
\hline \# & 900 & Right zygomatic & & \\
\hline
\end{tabular}

Table 1. Identifications of human remains found in 1998 at Scabba Wood rock shelter. 


\begin{tabular}{|c|c|c|c|c|}
\hline \multirow[t]{2}{*}{ Artefact type } & \multicolumn{4}{|c|}{ Excavation area } \\
\hline & Enclosure & Rock shelter & $\mathrm{U} / \mathrm{S}$ & Total \\
\hline \multirow[t]{2}{*}{ Blade } & 1 & 4 & 1 & 6 \\
\hline & $8.3 \%$ & $8.2 \%$ & $33.3 \%$ & $9.4 \%$ \\
\hline \multirow[t]{2}{*}{ Bladelet } & - & 4 & - & 4 \\
\hline & - & $8.2 \%$ & - & $6.3 \%$ \\
\hline \multirow[t]{2}{*}{ Chip } & 2 & 3 & - & 5 \\
\hline & $16.7 \%$ & $6.1 \%$ & - & $7.8 \%$ \\
\hline \multirow[t]{2}{*}{ Chisel arrowhead } & 1 & - & - & 1 \\
\hline & $8.3 \%$ & - & - & $1.6 \%$ \\
\hline \multirow[t]{2}{*}{ Flake } & 6 & 17 & - & 23 \\
\hline & $50.0 \%$ & $34.7 \%$ & - & $35.9 \%$ \\
\hline \multirow{2}{*}{ Fragmentary/Unclass./Other arrowhead } & - & 1 & - & 1 \\
\hline & - & $2.0 \%$ & - & $1.6 \%$ \\
\hline \multirow[t]{2}{*}{ Irregular waste } & 2 & 5 & - & 7 \\
\hline & $16.7 \%$ & $10.2 \%$ & - & $10.9 \%$ \\
\hline \multirow[t]{2}{*}{ Leaf arrowhead } & - & 4 & - & 4 \\
\hline & - & $8.2 \%$ & - & $6.3 \%$ \\
\hline \multirow[t]{2}{*}{ Misc. retouched flake } & - & 6 & 1 & 7 \\
\hline & - & $12.2 \%$ & $33.3 \%$ & $10.9 \%$ \\
\hline \multirow[t]{2}{*}{ Multi-platform flake core } & - & 1 & - & 1 \\
\hline & - & $2.0 \%$ & - & $1.6 \%$ \\
\hline \multirow[t]{2}{*}{ Other scraper } & - & 1 & - & 1 \\
\hline & - & $2.0 \%$ & - & $1.6 \%$ \\
\hline \multirow[t]{2}{*}{ Serrated flake } & - & 1 & - & 1 \\
\hline & - & $2.0 \%$ & - & $1.6 \%$ \\
\hline \multirow[t]{2}{*}{ Single platform flake core } & - & - & 1 & 1 \\
\hline & - & - & $33.3 \%$ & $1.6 \%$ \\
\hline \multirow[t]{2}{*}{ Unclassifiable/Fragmentary core } & - & 1 & - & 1 \\
\hline & - & $2.0 \%$ & - & $1.6 \%$ \\
\hline \multirow[t]{2}{*}{ Utilised/Edge damaged flake/Blade } & - & 1 & - & 1 \\
\hline & - & $2.0 \%$ & - & $1.6 \%$ \\
\hline \multicolumn{5}{|l|}{ Total } \\
\hline & 12 & 49 & 3 & 64 \\
\hline & $100.0 \%$ & $100.0 \%$ & $100.0 \%$ & $100.0 \%$ \\
\hline
\end{tabular}

Table 2. The frequency of lithic artefact types.

\begin{tabular}{lcc}
\hline Raw material description & Frequency & Percentage \\
\hline Chalk-derived flint with a white cortex and speckled inclusions & 54 & 84.4 \\
Black chert & 1 & 1.6 \\
Green tuff & 1 & 1.6 \\
Gravel-derived grey flint with abraded cortex & 4 & 6.3 \\
Translucent greyish brown flint & 3 & 4.7 \\
Opaque grey flint & 1 & 1.6 \\
Total & 64 & 100 \\
\hline
\end{tabular}

Table 3. The frequency of raw material types within the assemblage of worked stone. 


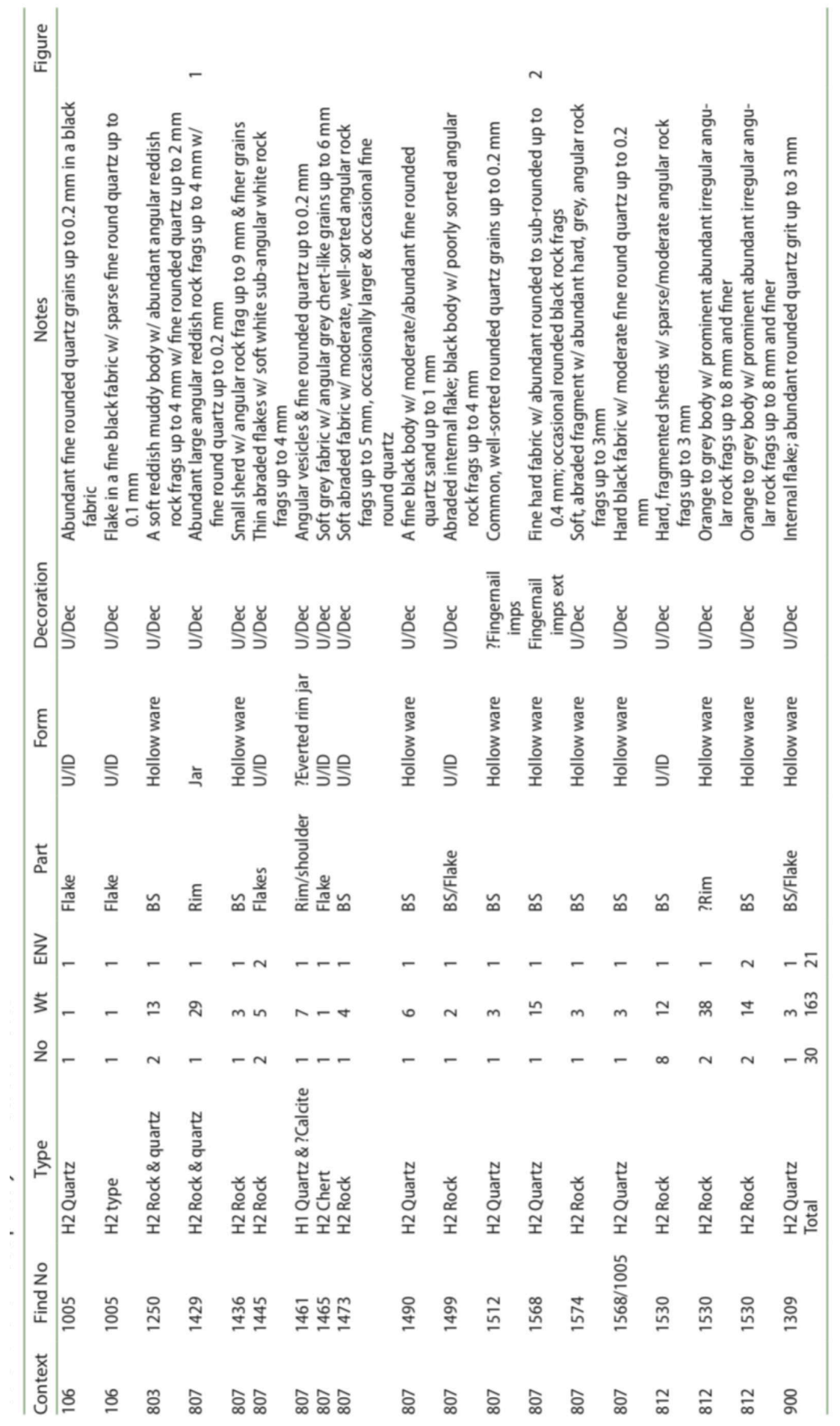

Table 4. Hand-made pottery from Scabba Wood. 


\begin{tabular}{|c|c|c|c|}
\hline Ware type & Description & Notes & References \\
\hline $\mathrm{H} 1$ & $\begin{array}{l}\text { Calcareous temper; chalk and/ } \\
\text { or calcite }\end{array}$ & $\begin{array}{l}\text { Nature of inclusions where iden- } \\
\text { tifiable noted as modifier }\end{array}$ & Didsbury $(2009,253-254)$ \\
\hline $\mathrm{H} 2$ & Non-soluble quartz temper & $\begin{array}{l}\text { Other rock fragments noted as } \\
\text { appropriate }\end{array}$ & Didsbury $(2009,253-254)$ \\
\hline H2/ETW & $\begin{array}{l}\text { Non-soluble'erratic' temper, } \\
\text { sometimes with quartz }\end{array}$ & $\begin{array}{l}\text { Some variety in the nature of the } \\
\text { rock fragments }\end{array}$ & $\begin{array}{l}\text { Didsbury (2009, 253-254), Rigby } \\
(2004,24-27)\end{array}$ \\
\hline $\mathrm{H} 3$ & $\begin{array}{l}\text { Mixed calcareous and non-solu- } \\
\text { ble rock temper }\end{array}$ & $\begin{array}{l}\text { A rare type with a diverse range } \\
\text { of temper }\end{array}$ & Didsbury $(2009,253-254)$ \\
\hline $\mathrm{H} 4$ & Vesicular fabrics & $\begin{array}{l}\text { Generally } \mathrm{H} 1 \text { with the calcareous } \\
\text { inclusions leached out by } \\
\text { acidic groundwater }\end{array}$ & Didsbury $(2009,253-254)$ \\
\hline
\end{tabular}

Table 5. Fabric type series for later prehistoric pottery in Yorkshire. 